\title{
Palaeoenvironmental changes recorded in the oxygen and carbon isotope composition of Kimmeridgian (Upper Jurassic) carbonates from central Poland
}

\author{
Hubert WIERZBOWSKI ${ }^{1, *}$ \\ 1 Polish Geological Institute - National Research Institute, Rakowiecka 4, 00-975 Warszawa, Poland
}

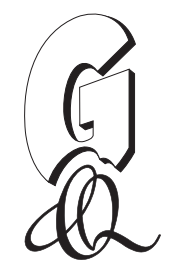

Wierzbowski, H., 2019. Palaeoenvironmental changes recorded in the oxygen and carbon isotope composition of Kimmeridgian (Upper Jurassic) carbonates from central Poland. Geological Quarterly, 63 (2): 359-374, doi: 10.7306/gq.1471

Associate Editor - Michał Zatoń

\begin{abstract}
Oxygen and carbon isotope ratios of well-preserved calcitic bivalves from the Lower-lowermost Upper Kimmeridgian of Central Poland (SW margin of the Holy Cross Mountains) have been studied to reconstruct palaeoenvironmental conditions and variations in ancient water chemistry. Low and scattered $\delta^{18} \mathrm{O}$ and $\delta^{13} \mathrm{C}$ values of bivalve shells from shallow carbonate deposits of the Hypselocyclum and the Hypselocyclum-Divisum zone boundary ( -3.5 to -1.5 , and 2.6 to $4.0 \%$, respectively) are a result of salinity changes and local variations in the composition of dissolved inorganic carbon (DIC) in conditions of restricted water circulation. A slight increase in bivalve $\delta^{13} \mathrm{C}$ values and more densely clustering of $\delta^{18} \mathrm{O}$ values is observed after the marine transgression at the Divisum-Mutabilis zone boundary. A global decrease of $\delta^{13} \mathrm{C}$ values of marine carbonates is partly recorded in Lower-lowermost Upper Kimmeridgian bulk carbonates from central Poland (from the Radomsko Elevation and the Wieluń Upland). Local negative shifts and data scatter are, however, observed in rocks deposited in a very shallow environment of carbonate platforms during the Platynota and Hypselocyclum chrons. This interval corresponds to the uppermost part of the lowstand systems tract of a major regressive trend, which had started in the Oxfordian.
\end{abstract}

Key words: Upper Jurassic, stable isotopes, oysters, Trichites, carbonate platform, salinity effects.

INTRODUCTION

Lower-lowermost Upper Kimmeridgian (Platynota-Mutabilis zones) strata of central Poland, which were deposited during phases of growth and decay of shallow-water carbonate platforms, are poorly investigated as regards their mineralogical and geochemical compositions. This is due to the restricted outcrop area and problems with dating and correlation of the beds. Recent studies of Matyja et al. (2006), Matyja (2011), Wierzbowski (2017), and Wierzbowski and Głowniak (2018) have, however, allowed re-definition of lithostratographical units and precise biostratigraphical dating of the Kimmeridgian succession in the Wielun Upland, the Radomsko Elevation and the SW margin of the Holy Cross Mountains.

The present study is based on accessible Lower-lowermost Upper Kimmeridgian exposures in these regions and archival samples. Well-preserved and stratigraphically well-dated bivalve shells were sampled from the Małogoszcz section (SW margin of the Holy Cross Mountains). Bulk carbonates from the Wielun Upland, its vicinity, and the Rogaszyn section (the Radomsko Elevation) were additionally investigated (Fig. 1).

\section{*E-mail: hwier@pgi.gov.pl}

Received: December 24, 2018; accepted: March 14, 2019; first published online: June 3, 2019
Oxygen and carbon isotope analyses have been undertaken to provide information on the environmental conditions recorded in marine carbonates, including variations in water temperatures, salinity and biological productivity. The results obtained are compared with the coeval geochemical record of other regions to discriminate between local and global factors. Longterm bathymetry and water circulation changes, which occurred in the epicontinental Polish basin during the Late Jurassic, are additionally discussed as an alternative factor controlling the isotope record. The isotope data provided may have broader significance due to the similarity in facies development of Kimmeridgian deposits in various parts of Europe.

\section{GEOLOGICAL SETTING}

Deep-water biohermal and bedded Oxfordian-lowermost Kimmeridgian limestones and marls of the sponge megafacies are overlain in central Poland by relatively shallow-water Lower Kimmeridgian carbonate facies (Kutek, 1968, 1994; Matyja, 1977, 2011; Matyja et al., 2006; Matyja and Wierzbowski, 2014; Wierzbowski, 2017). This change was a result of pronounced shallowing of the depositional basin and progradation of the carbonate platform from east and north-east to west and south-west (Matyja and Wierzbowski, 2014). The shallow-water carbonate sedimentation started in the latest Planula Chron on the SW margin of the Holy Cross Mountains and the Radomsko El- 


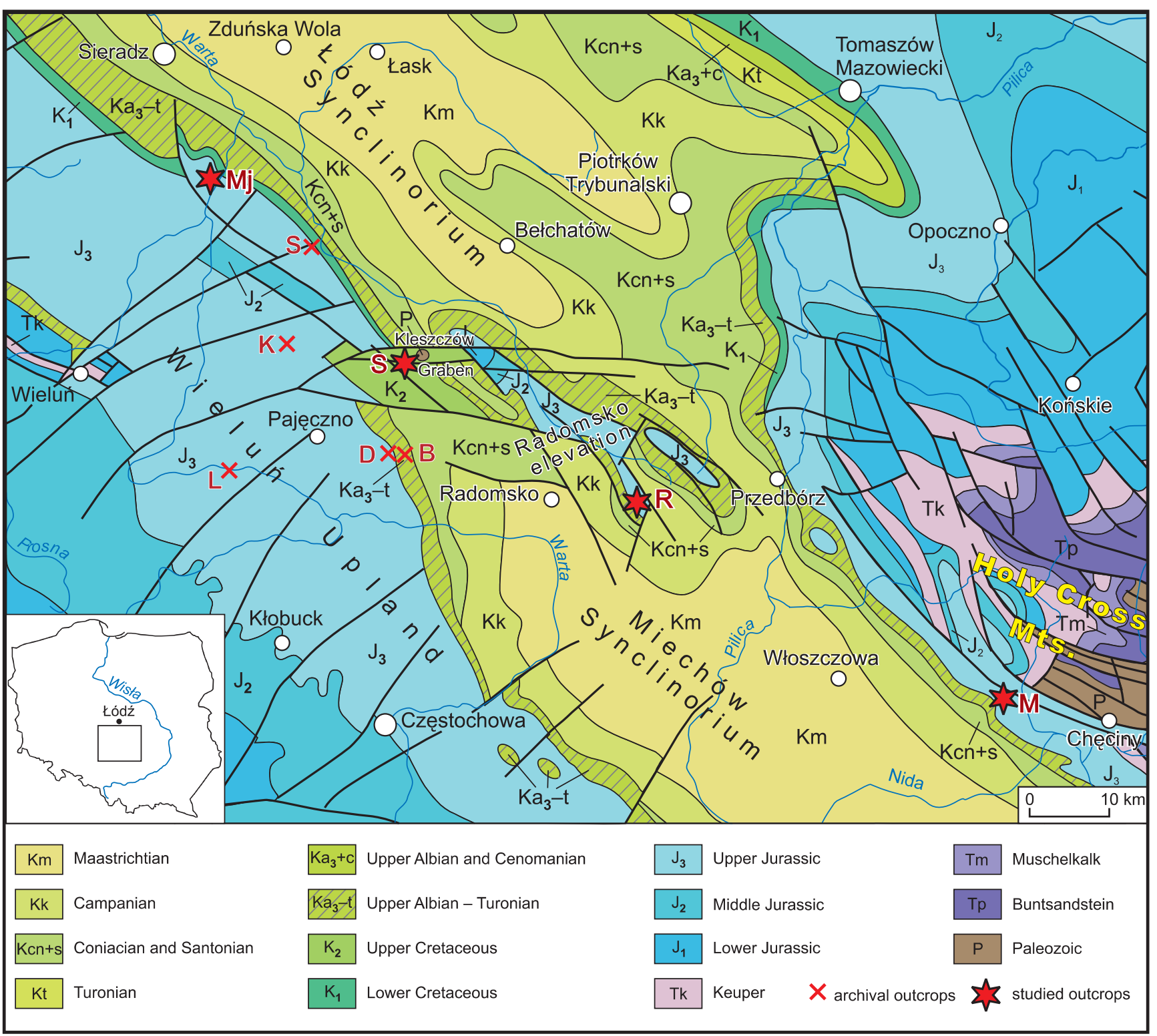

Fig. 1. Geological map of central Poland (after Dadlez et al., 2000) with location of the study area

Outcrops studied: M - Małogoszcz, Mj - Majaczewice, R - Rogaszyn, S - Szczerców; archival outcrops: B - Błota Kruplińskie (cores KP2 and KP3), D - Dubidze (core 6W), K - Kule (84), L - Lisowice (PJ110), S - Sarnów

evation, and in the Platynota Chron in the Wieluń Upland (Matyja, 2011; Matyja and Wierzbowski, 2014; Wierzbowski, 2017; Wierzbowski and Głowniak, 2018).

Moderately shallow and shallow-water Lower Kimmeridgian deposits, which are nowadays restricted to the eastern part of the Wieluń Upland and its vicinity, overlie well-bedded micritic limestones (Wolbrom Limestone Member) and marls (Latosówka Marl Member) of the Pilica Formation belonging to the sponge megafacies. The Lower Kimmeridgian deposits studied comprise:

- bedded chalky limestones with siliceous sponges rich in benthic fauna, and micritic limestones and marls of the Prusicko Formation known from the Wieluń Upland and dated to the Platynota Zone,

- oolitic and chalky limestones with oncolites, and marls of a so-called "oolitic" formation from the Wielun Upland, as- signed to the uppermost Platynota Zone and lower and middle parts of the Hypselocyclum Zone,

- marls, marly- and micritic limestones with common bivalves and locally occurring oncolites of the Burzenin Formation, which are assigned to the upper part of the Hypselocyclum and the Divisum Zone in the Wielun Upland, and to almost the whole Hypselocyclum and the Divisum Zone north of the Wieluń Upland (Wierzbowski, 2017; Fig. 2).

The deposition of the Prusicko Formation in the Wielun Upland took place on the outer slope of a carbonate ramp, in a relatively shallow environment, below the fair-weather wave base. Major shallowing, observed in the Wielun Upland, is marked by occurrences of oolitic limestones belonging to the so-called "oolitic" formation, which are exposed in the Szczerców outcrop (Fig. 3). These strata are, in turn, overlain by transgressive deposits of the Burzenin Formation, partly exposed in the 


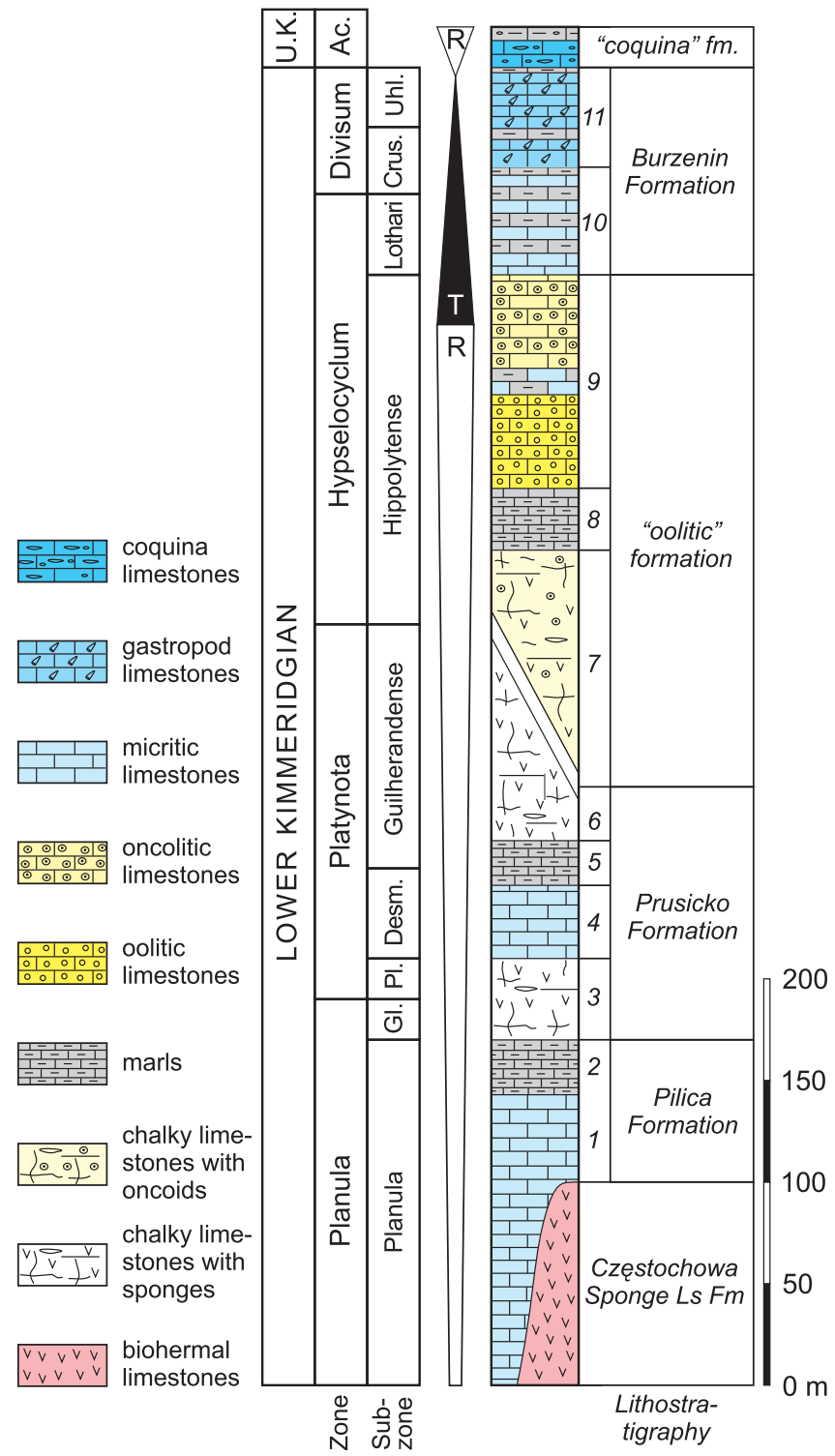

Fig. 2. Generalized lithology, lithostratigraphy, and transgressive-regressive sequences of the Wieluń Upland (Planula to Platynota-Hypselocyclum zone boundary) and its northern vicinity (Platynota-Hypselocyclum zone boundary to Acanthicum Zone; after Wierzbowski, 2017)

Ac. - Acanthicum, Crus. - Crussoliense, Desm. - Desmoides, GI. Galar, PI. - Polygyratus, Uhl. - Uhlandi; 1 - Wolbrom Limestone Member, 2 - Latosówka Marl Member, 3 - Kuchary Chalky Limestone Member, 4 - Skowronów Limestone Member, 5 - Góry Marl Member, 6 - Kule Chalky Limestone Member, 7 - unit A, 8 Kiełczygłów Marl Member (unit B), 9 - units C, D, E, F, 10 Majaczewice Member (units G, H), 11 - Sarnów Gastropod Limestone Member (unit I)

Majaczewice section (Fig. 4), which were deposited in a moderately shallow sea after a decline of the shallow water carbonate platform (Wierzbowski, 2017). Deposition of the Burzenin Formation started earlier in a deeper part of the basin, north of the Wielun Upland, directly above the moderately deep-water Pilica Formation, where the Prusicko and the "oolitic" formation do not occur. Part of the basal deposits of the Burzenin Formation, north of the Wielun Upland, i.e. the Brzyków Oncolite Bed dated to the upper part of the Hippolytense Subzone of the Hypselo- cyclum Zone was, however, formed in a relatively shallow environment (Wierzbowski, 2017). This may be treated as an indicator of the maximum regression surface of the lowstand systems tract, which corresponds to thicker oolite deposits from the south. A major part of the Burzenin Formation from the Wielun Upland and its vicinity, with abundant condensation surfaces, shows a transgressive character and was deposited starting from the Lothari Subchron of the Hypselocyclum Chron to the end of the Divisum Chron (Wierzbowski, 2017). Younger Acanthicum ( $\approx$ Mutabilis) deposits of the Upper Kimmeridgian in the study area, which are not exposed nowadays, consist of bivalve coquinas (a so-called "coquina" formation) and show a slightly regressive character (Wierzbowski, 2017).

Oncolite-micritic limestones (unit 1) are exposed in the oldest part of the Rogaszyn section on the Radomsko Elevation. They are dated to the Desmoides Subzone of the Platynota Zone of the Lower Kimmeridgian (Kutek, 1968; Wierzbowski and Głowniak, 2018; see also Fig. 5). Younger strata in this section consist of intercalations of marls, micritic and subordinate organodetrital limestones (units 2-8) and represent the upper part of the Platynota Zone (Wierzbowski and Głowniak, 2018). Higher, above an omission surface, occur biodetrital limestones, which gradually pass into oncolitic limestones with oolites (unit 9). The latter strata are assigned to the Hippolytense Subzone of the Hypselocyclum Zone (Wierzbowski and Głowniak, 2018). In the youngest part of the Rogaszyn Quarry, which is poorly exposed nowadays, there occur brittle marls (unit 10) as well as micritic-oolitic limestones and marls (units 11 and 12) of the Lothari Subzone of the Hypselocyclum Zone (Wierzbowski and Głowniak, 2018).

A major part of the Rogaszyn section (units 1-11) consists of shallow water deposits of the carbonate platform. These deposits constitute a lateral equivalent of the "oolite" formation and the Prusicko Formation, known from the Wielun Upland (Wierzbowski and Głowniak, 2018; Fig. 5). The very small thickness of the carbonate platform deposits in the Radomsko Elevation is, however, unusual, and may result from tectonic movements of local fault blocks (Wierzbowski and Głowniak, 2018). The demise of the shallow-water carbonate platform took place in the latest Hypselocyclum Chron (during the Lothari Subchron) and is marked by the occurrence of deeper water facies of unit 12 (Wierzbowski and Głowniak, 2018), which corresponds to the Burzenin Formation.

The Lower Kimmeridgian succession of the Małogoszcz section at the SW margin of the Holy Cross Mountains begins with the "oolite" formation assigned to the Platynota-Hypselocyclum zones (Kutek, 1968, 1994; Matyja et al., 2006; Matyja, 2011; see also Fig. 6). It consists of two oolitic units (the Lower Oolite and the Upper Oolite) underlain by Pelitic Limestones and divided by the Banded Limestone Member. These units are, in turn, overlain by the Oncolite Layer, the Oolite-Platy Member, as well as marls and marly limestones (Shaly Limestones and Underlying Shales). All the rocks of the "oolite" formation were formed during various phases of growth of a shallow-water carbonate platform (Matyja et al., 2006; Matyja, 2011). A younger part of the Małogoszcz section begins with an encrusted hardground around the Hypselocyclum-Divisum zone boundary. This hardground is overlain by the "coquina" formation, which consists of the Skorków Lumachelle and Upper Platy Limestones. Deposition of the "coquina" formation reflects a deepening of the basin during the Divisum Chron (Matyja et al., 2006; Matyja, 2011). The top of the Małogoszcz section consists of marls and marly shales with intercalations of organodetrital limestones (Top Shales), which are dated to the Upper Kimmeridgian Mutabilis ( $\approx$ Acanthicum) Zone (Kutek, 1968, 1994; Matyja et al., 2006; Matyja, 2011). These deposits 


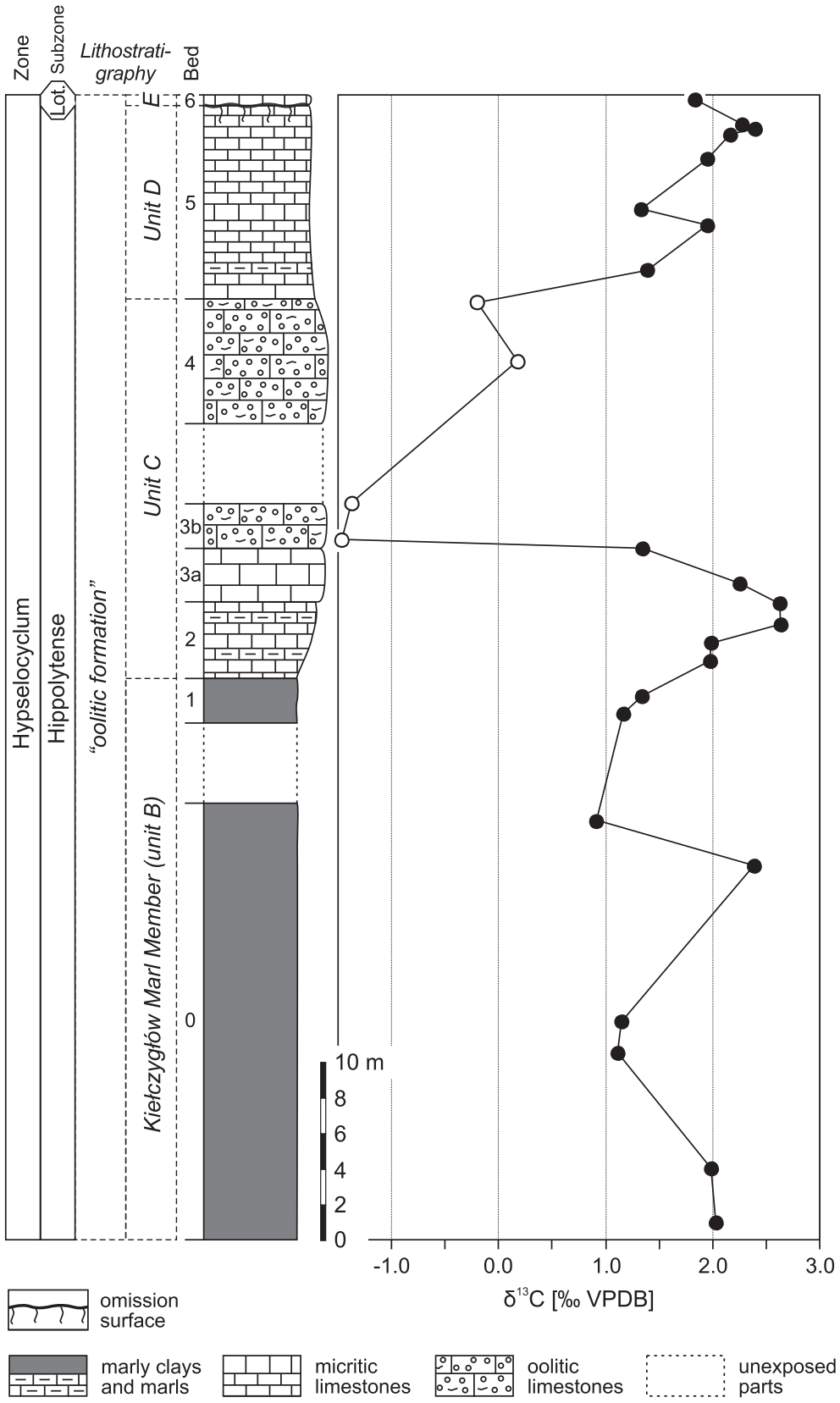

Fig. 3. Bulk carbonate carbon isotope record of the Szczerców section (northern border of the Wielun Upland)

Bio- and lithostratigraphy are given after Wierzbowski (2017); data points of altered samples (see text) are marked with open circles; Lot. - Lothari Subzone

show a slightly regressive character, and are intercalated, especially in their higher part, with bivalve coquinas.

Although continuous limestone sedimentation prevailed in the Early Kimmeridgian of the study area, limestone beds are intercalated with marly layers. The appearance of the Latosówka Marl Member within the Pilica Formation, the Góry Marl Member within the Prusicko Formation and the Kiełczygłów Marl Member within coeval parts of the "oolitic" and the Burzenin formations as well as unnamed marls within the uppermost part of the Burzenin Formation from the Wielun Upland and its vicinity, may be climatically or tectonically induced (Wierzbowski, 2017). The marlstone members from the Wieluń Upland correlate with coeval marly beds from the Radomsko Elevation and the SW margin of the Holy Cross Mountains (cf. Matyja and Wierzbowski, 2006; Matyja, 2011; Wierzbowski, 2017). A deepening event on the Wielun Upland, which is marked by the demise of carbonate platforms in the Lothari Subchron of the Hypselocyclum Chron, is almost coeval with the occurrence of deeper water facies on the Radomsko Elevation (Wierzbowski, 2017; Wierzbowski and Głowniak, 2018). It predates, however, a similar episode known from the SW margin of the Holy Cross Mountains, which is assigned to the Hypselocyclum-Divisum Chron boundary (Kutek, 1994; Matyja et al., 2006; Matyja, 2011). Shallow-water carbonate sedimentation lasted longer at the SW margin of the Holy Cross Mountains probably because of the lesser depth of this part of the epicontinental Polish basin. In all areas studied, deposits of carbonate platforms are overlain by deeper water facies of the uppermost Lower and the Upper Kimmeridgian (Matyja and Wierzbowski, 2014).

\section{MATERIAL AND METHODS}

Deltoideum delta (oysters) and Trichites (pinnid bivalves), which are abundant in the Małogoszcz Quarry section (Fig. 6), were collected for isotope studies. A few undetermined oyster shells were also collected from the Małogoszcz and the Szczerców sections. Thin-sections prepared from the bivalve shells were studied using a cold cathodoluminescence microscope. Non-luminescent or very weakly luminescent shell fragments (38 samples), away from the hinge or the muscle scar areas, were cleaned manually, using a microdrill, from sediment remains and borings. The samples were ground in an agate mortar. Aliquots of carbonate powders were used for chemical and oxygen and carbon isotope analyses.

65 bulk carbonate samples (limestones, marly limestones, marls and marly clays) were collected manually from exposures at Szczerców, Majaczewice, and Rogaszyn, which are assigned to the Platynota Zone and a lower part of the Hypselocyclum Zone (Figs. 3-5). The sample set has been supplemented with 31 archival samples derived from W.C. Kowalski's collection, who studied the Lower Kimmeridgian in exposures located north of the Wielun Upland (cf. Kowalski, 1958) and from A. Wierzbowski's collection, who mostly studied borehole cores from the northern border of the Wielun Upland (cf. Wierzbowski, 2017). The majority of supplementary samples come from the vicinity of the Majaczewice section (localities: Góry Wapienne, Burzenin 47, Burzenin 16/9, Burzenin 16/2) and the Szczerców outcrop (boreholes: 37/13.5, PD20B, 130SP, PW408, KT109). Other localities are indicated on Figure 1.

$\mathrm{Ca}, \mathrm{Mg}, \mathrm{Sr}, \mathrm{Na}, \mathrm{Mn}$ and $\mathrm{Fe}$ concentrations in bivalve shells were determined by means of the ICP-OES (Inductively Coupled Plasma Optical Emission Spectrometry) method at the Polish Geological Institute - National Research Institute. $50-100 \mathrm{mg}$ samples were dissolved in $5 \mathrm{wt}$. \% hydrochloric acid.

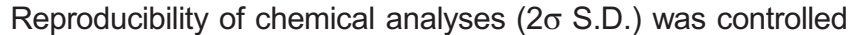
by multiple analyses of samples and averages as follows: $0.7 \%$ for $\mathrm{Ca}, 1.6 \%$ for $\mathrm{Mg}, 1.1 \%$ for $\mathrm{Sr}, 4.8 \%$ for $\mathrm{Na}, 2.9 \%$ for $\mathrm{Mn}$, and $14 \%$ for Fe. Repeated analyses of JLs-1 calcite and JDo-1 do- 


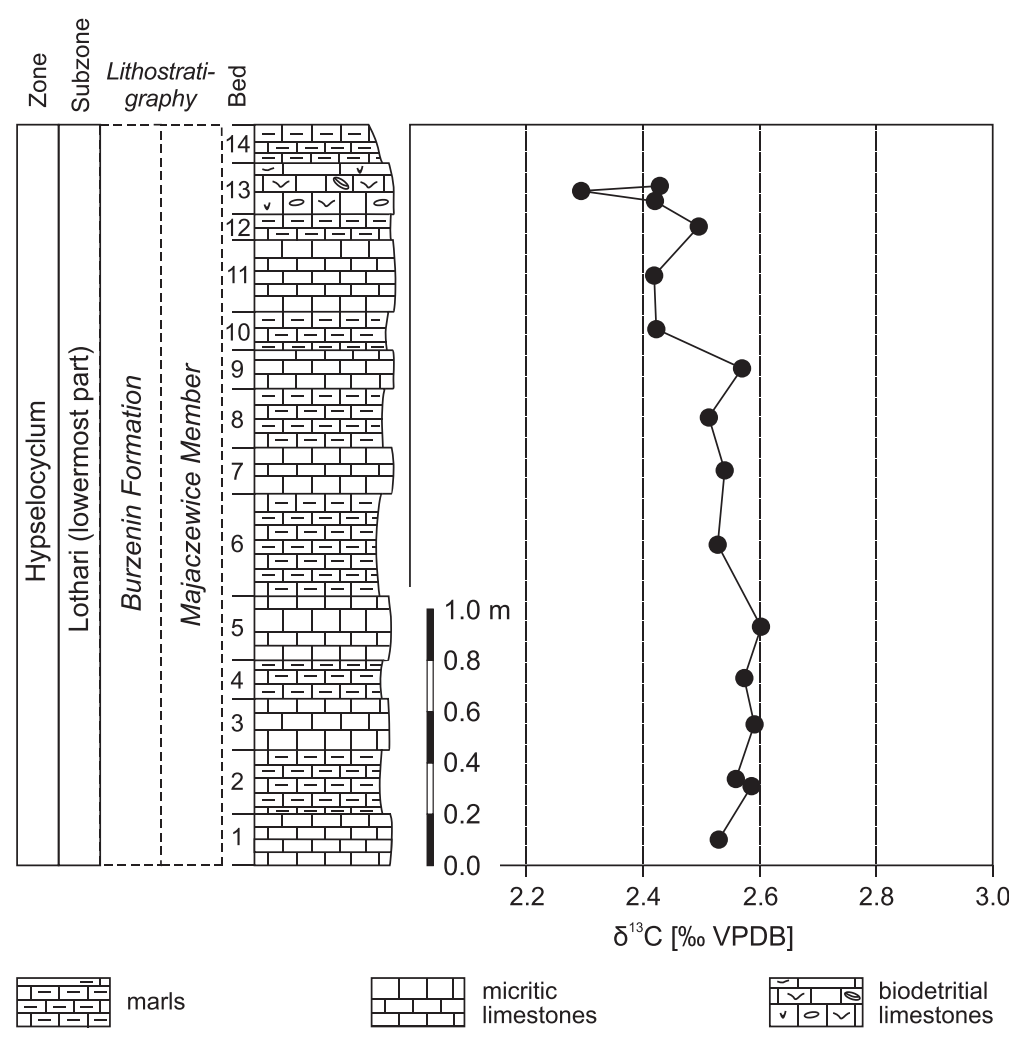

Fig. 4. Bulk carbonate carbon isotope record of the Majaczewice section (north of the Wielun Upland)

Bio- and lithostratigraphy are given after Wierzbowski (2017)

lomite references (cf. Imai et al., 1996) yielded accuracies of measurements ( $2 \sigma$ S.D.) better than $2.2 \%$ for $\mathrm{Ca}, 1.5 \%$ for $\mathrm{Mg}$, $1.3 \%$ for $\mathrm{Sr}, 4.5 \%$ for $\mathrm{Mn}$, and $12.1 \%$ for Fe. The presence of non-carbonate iron compounds may have affected reproducibility and accuracy of Fe analyses. The accuracy of $\mathrm{Na}$ analyses cannot be specified because of low sodium concentrations in the references.

Oxygen and carbon isotope analyses of bulk carbonates and bivalve shells were conducted at the GeoZentrum Nordbayern, University of Erlangen-Nuremberg (Germany). Samples were reacted with $100 \%$ phosphoric acid at $70^{\circ} \mathrm{C}$ using a Gasbench I/ connected to a ThermoFisher Delta V Plus mass spectrometer. All values are reported in per mil relative to the VPDB scale by assigning $\delta^{13} \mathrm{C}$ values of $+1.95 \%$ to NBS19 and $-47.3 \%$ to IAEA-CO9 and $\delta^{18} \mathrm{O}$ values of $-2.20 \%$ to NBS 19 and $-23.2 \%$ to NBS18. Reproducibility of measurements was monitored by replicate analyses of laboratory standards Sol 2 $(n=24)$ and Erl $5(n=18)$. Reproducibility for $\delta^{13} \mathrm{C}$ and $\delta^{18} \mathrm{O}$ values was 0.09 and $0.10 \%$ ( $\pm 2 \sigma$ S.D.) for Sol 2 , and $0.12 \%$ and $0.12 \%$ ( $\pm 2 \sigma$ S.D.) for Erl 5, respectively.

To calculate $\delta^{18} \mathrm{O}$-derived temperatures for calcite the relationship of O'Neil et al. (1969) modified by Friedman and O'Neil (1977), along with the SMOW to PDB scales conversion given by Friedman and O'Neil (1977), was used:

$$
1000 \mathrm{In} \alpha_{\text {calcite-water }}=2.78 \cdot 10^{6} / \mathrm{T}^{2}-2.89
$$

where: $\alpha_{\text {calcite-water }}-$ oxygen isotope fractionation factor between calcite and water, $\mathrm{T}$ - temperature in Kelvin.

Temperatures calculated for the measured range of $\delta^{18} \mathrm{O}_{\text {calcite }}$ values using the equation of Friedman and O'Neil
(1977) are almost indistinguishable from temperatures calculated using the equation of Anderson and Arthur (1983):

$$
T\left({ }^{\circ} \mathrm{C}\right)=16.0-4.14 \cdot\left(\delta_{\mathrm{c}}-\delta_{\mathrm{w}}\right)+0.13 \cdot\left(\delta_{\mathrm{c}}-\delta_{\mathrm{w}}\right)^{2}
$$

where: $\delta_{c}$ - oxygen isotope composition of carbonate on the PDB scale, $\delta_{w}$ - oxygen isotope composition of water on the SMOW scale.

Palaeotemperatures calculated using both equations are shown on Figure 6 for comparison.

\section{DIAGENETIC ALTERATION OF BIVALVE SHELLS}

Oyster shells posses foliated microstructures and are made of calcite (Esteban-Delgado et al., 2008). Trichites shells are primarily built of coarse calcite prisms (Chateigner et al., 2002). Although a thin inner, aragonitic layer occurs in the pointed area of modern pinnid shells its remnants are usually not found in fossil Trichites (cf. Chateigner et al., 2002; Sturman et al., 2014). The aragonite shell layer was also not observed in the Trichites shells studied.

Diagenetic alteration of skeletal calcite can be screened using cathodoluminescence studies and analyses of minor and trace element concentrations. Iron and manganese contents of marine calcite increases as a result of alteration under reducing conditions. A diagenetic decrease in strontium content is, in turn, observed because of its low concentration in freshwater and lesser partitioning of this element in inorganic calcites (Veizer, 1983; Brand and Veizer, 1980; Marshall, 1992; Ullmann and Korte, 2015). In addition, diagenetic $\mathrm{Mn}^{2+}$ ions activate bright orange-red cathodoluminescence in calcites, which is typical of altered shell material (Marshall, 1992; Savard et al., 1995). Pristine carbonate shells may, however, show dull luminescence with narrow brighter bands (Barbin, 2000, 2013).

The oyster and Trichites shells studied from the Lower Kimmeridgian of central Poland are non-luminescent or show different cathodoluminescence intensities from dull to bright (Fig. 7). As bright, orange-red luminescence is interpreted as a result of diagenetic alteration, only non-luminescent or dully luminescent bivalve shells were selected for chemical and isotope analyses.

The bivalves shells studied from central Poland are characterized by variable minor and trace element concentrations: $\mathrm{Mn}$ from below detection limit (1 ppm) to $74 \mathrm{ppm}$, Fe from below detection limit (20 ppm) to $596 \mathrm{ppm}$, and Sr from 592 to $860 \mathrm{ppm}$ (Table 1). A strong, correlation is observed between Fe and $\mathrm{Mn}$ contents in the shells (Fig. 8). Threshold limits of $\mathrm{Mn} \leq 100 \mathrm{ppm}$, $\mathrm{Fe} \leq 250 \mathrm{ppm}$, and $\mathrm{Sr} \geq 490 \mathrm{ppm}$ may be accepted as indicative of well-preserved Jurassic calcite bivalve shells according to Wierzbowski and Joachimski (2007), and Wierzbowski et al. (2016). The given limits of manganese and iron concentrations are in line with the data of Jones et al. (1994). The accepted manganese and strontium cut-off limits are also similar to the limits specified for Jurassic bivalves by Anderson et al. (1994), Price and Page (2008), Price and Teece (2010), and Zuo et al. (2019) although the latter authors report higher iron contents. 


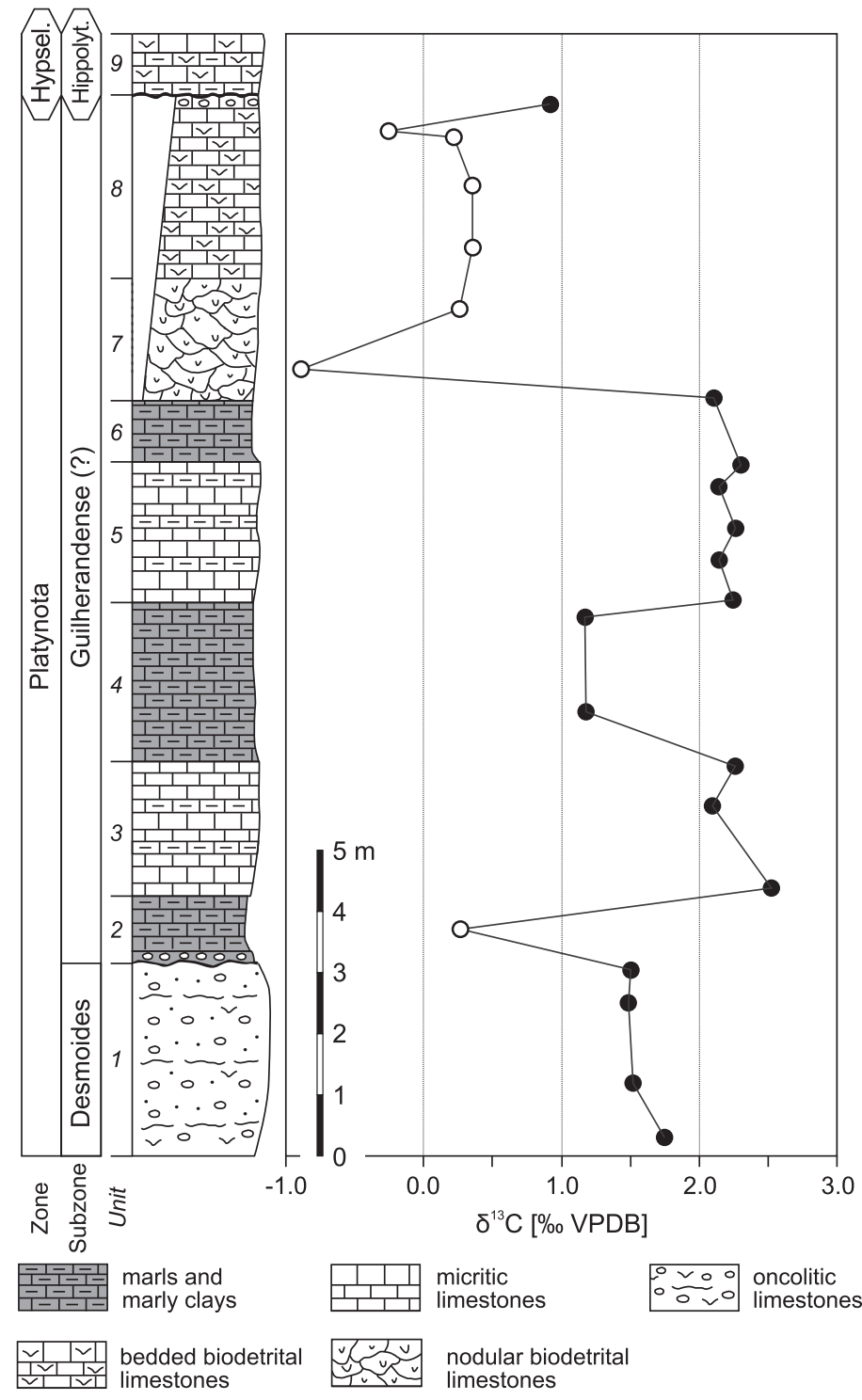

Fig. 5. Bulk carbonate carbon isotope record of the Rogaszyn section (the Radomsko Elevation)

Biostratigraphy and lithological units are given after Wierzbowski and Głowniak (2018); data points of altered samples (see text) are marked with open circles;

Hypsel. - Hypselocyclum Zone, Hippolyt. - Hippolytense Subzone

Six bivalve shells with Fe contents above 250 ppm were removed from the well-preserved sample set. After removal of these samples the remaining sample set is characterized by concentrations of $\mathrm{Mn} \leq 27 \mathrm{ppm}, \mathrm{Fe} \leq 206 \mathrm{ppm}$, and $\mathrm{Sr} \geq 631$ $\mathrm{ppm}$, and a moderate correlation between $\mathrm{Fe}$ and $\mathrm{Mn}$ contents (Fig. 8). All well-preserved bivalve shells (32 samples) come from the Małogoszcz section.

\section{RESULTS}

\section{OXYGEN AND CARBON ISOTOPE COMPOSITION OF BIVALVE SHELLS}

$\delta^{18} \mathrm{O}$ values of well-preserved bivalve shells from the Małogoszcz section vary between -0.6 and $-3.5 \%$ (Fig. 6 and Table 1). Oxygen isotope values from the Upper Oolite and the
Skorków Lumachelle (the Hypselocyclum and the lowermost Divisum zones) are characterized by a significant scatter (from -3.5 to $-1.5 \%$ ). Bivalve $\delta^{18} \mathrm{O}$ values from the Upper Platy Limestones and Top Shales (the Divisum-Mutabilis zone boundary) show a lesser spread (from -3.4 to $-2.2 \%$ ). Two oxygen isotope data points from two oysters from the upper part of the Skorków Lumachelle (the middle Divisum Zone) are higher ( -1.0 to $-0.6 \%$ ) than all other data. No clear temporal trend is observed within the oxygen isotope dataset.

$\delta^{13} \mathrm{C}$ values of well-preserved bivalve shells from the Małogoszcz section vary between 2.6 and 4.2\%o (Fig. 6 and Table 1). Carbon isotope values from the Upper Oolite and the Skorków Lumachelle (the Hypselocyclum and the lowermost Divisum zones) are lower and show a larger scatter (from 2.6 to $4.0 \%$ ) than the values from the Upper Platy Limestones and Top Shales (the Divisum-Mutabilis zone boundary), which vary between 3.6 to $4.2 \%$. A gradual increase in bivalve $\delta^{13} \mathrm{C}$ values upsection is observed, except for two low $\delta^{13} \mathrm{C}$ values from the upper part of the Skorków Lumachelle (the middle Divisum Zone).

\section{CARBON ISOTOPE COMPOSITION OF BULK CARBONATES}

Bulk carbonate $\delta^{13} \mathrm{C}$ values range from -1.5 to $2.7 \%$ in the entire study interval. The most variable carbon isotope values are documented from the Szczerców (-1.5 to $2.6 \%$ ) and the Rogaszyn section ( -0.9 to $2.5 \%$; Fig. 9). Lesser variations of $\delta^{13} \mathrm{C}$ values are noted in the samples derived from boreholes $(0.0$ to $2.5 \%$ ), small exposures of the Lower Kimmeridgian deposits (1.1 to $2.7 \%$ ) and from the Majaczewice section (2.3 to $2.6 \%$ ). There is no distinct difference in $\delta^{13} \mathrm{C}$ values of co-occurring limestone and marly beds.

Strong correlations between bulk carbonate $\delta^{18} \mathrm{O}$ values and $\delta^{13} \mathrm{C}$ values, which may be linked to diagenetic alteration, is observed in the datasets from the Rogaszyn and the Szczerców section (Fig. 9). Since diagenetic processes may have affected the original carbon isotope composition of the highly weathered subsurface or oolitic parts of these sections, they are discussed later in the text.

\section{DISCUSSION}

\section{OXYGEN AND CARBON ISOTOPE RECORDS OF BIVALVE SHELLS}

Modern oysters precipitate shell calcite in the oxygen isotope equilibrium with ambient sea water or very close to it (Hong et al., 1995; Kirby et al., 1998; Surge et al., 2001, 2003; Titschack et al., 2010; Ullmann et al., 2010). The equilibrium precipitation of oxygen isotopes by Jurassic oysters is documented by the similarity of their $\delta^{18} \mathrm{O}$ values with those of co-occurring benthic and necto-benthic molluscs and brachiopods (Anderson et al., 1994; Wierzbowski and Joachimski, 2007; Price and Teece, 2010; Mettam et al., 2014). Although slight disequilibrium fractionation of carbon isotopes (of $\sim-1.0 \%$, except shell portions precipitated 


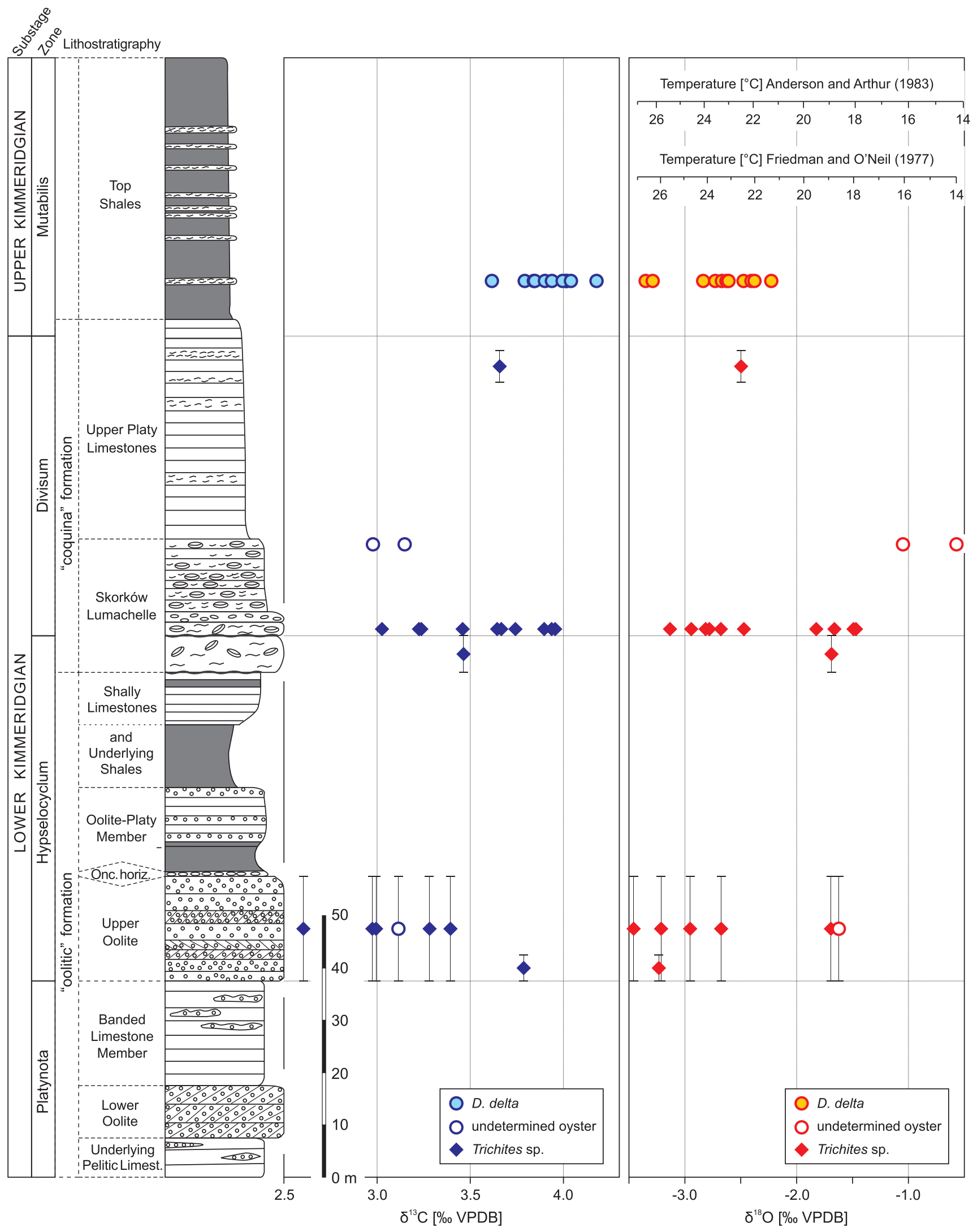

Fig. 6. Oxygen and carbon isotope records of the Małogoszcz section (SW margin of the Holy Cross Mountains)

Bio- and lithostratigraphy are given after Matyja et al. (2006), Matyja (2011) and A. Wierzbowski's (pers comm., 2017) 

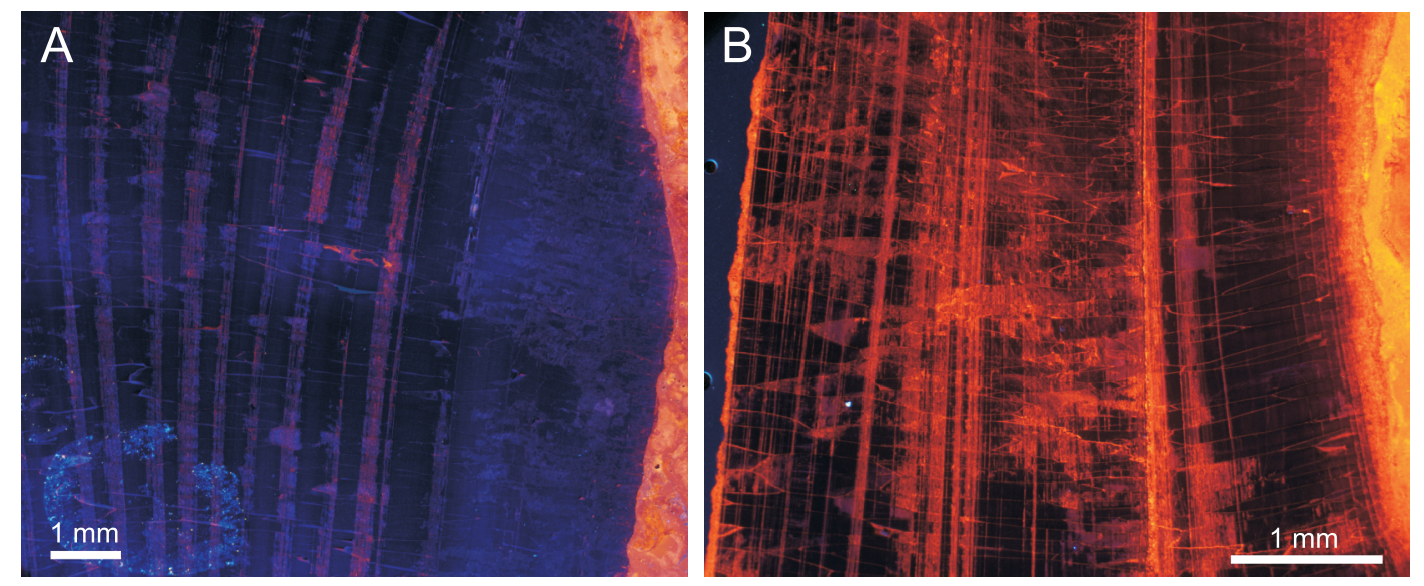

Fig. 7. Cathodoluminescence photomicrographs

A - well-preserved, dully-luminescent Trichites shell (sample M80, Upper Oolite, Hypselocyclum Zone, Małogoszcz section); B - altered oyster shell, showing moderate to bright luminescence intensities (sample M41, bed 5, Hypselocyclum Zone, Szczerców section)

during cold seasons) is observed in modern oysters (Surge et al., 2001, 2003; Titschack et al., 2010), Jurassic oysters show higher $\delta^{13} \mathrm{C}$ values than those of coeval molluscs (Wierzbowski and Joachimski, 2007; Price and Teece, 2010; Mettam et al., 2014). Accordingly, it may be assumed that the Jurassic oysters exerted relatively small vital effects in carbon isotope composition. In addition, Brigaud et al. (2009), Lathuilière et al. (2015), and Zuo et al. (2019) have recently shown that isotope signatures of Upper Jurassic Trichites are similar to those of coeval oysters and may be used as a reliable proxy for ancient water temperatures.

The oxygen isotope composition of marine calcite, precipitated in isotopic equilibrium with ambient sea water, is dependent on the temperature and oxygen isotope composition of ambient water. $\delta^{13} \mathrm{C}$ values of calcite precipitated in isotopic equilibrium vary, in turn, along with primary fluctuations in the composition of dissolved inorganic carbon (DIC).

Relatively scattered $\delta^{18} \mathrm{O}$ and $\delta^{13} \mathrm{C}$ values of bivalve shells from the lower part of the Małogoszcz section i.e., the Upper Oolite and a lower part of the Skorków Lumachelle (the Hypselocyclum and the lowermost Divisum zones; Fig. 6) may indicate considerable variations in water temperatures, salinity and the carbon isotope composition of DIC. Early Kimmeridgian carbonate platforms from the SW margin of the Holy Cross Mountains grew in a shallow basin, above storm wave-base (Matyja, 2011). Significant freshwater inflow from land areas or an enhanced evaporation rate may have caused temporal variations in $\delta^{18} \mathrm{O}_{\text {water }}$ values. River water rich in terrestrial organic matter or oxidation of marine organic carbon during the process of water-mass ageing (cf. Patterson and Walter, 1994) may, in turn, have produced variations in the carbon isotope composition of DIC. More densely clustered $\delta^{18} \mathrm{O}$ and $\delta^{13} \mathrm{C}$ data points of bivalves from the upper part of the Małogoszcz section i.e. the Upper Platy Limestones and the Top Shales (the Divisum-Mutabilis zone boundary) probably indicate more stable water temperature and chemistry, after a sea level rise and drowning of the shallow water carbonate platform (cf. Matyja et al., 2006; Matyja, 2011). Although $\delta^{13} \mathrm{C}$ values of two oysters from the upper part of the Skorków Lumachelle are relatively low, a general increase in mean bivalve $\delta^{13} \mathrm{C}$ value (by $\sim 0.5 \%$ ) towards the top of the Małogoszcz section is observed. This may be linked to a diminishing inflow of freshwater enriched in the light $\delta^{12} \mathrm{C}$ isotope and a higher rate of water exchange and circulation.
Palaeotemperatures calculated from oxygen isotope ratios of bivalves from the Upper Oolite and the lower part of the Skorków Lumachelle (the Hypselocyclum and the lowermost Divisum zones), assuming normal marine salinity and a mean $\delta^{18} \mathrm{O}_{\text {seawater }}$ value of $-1 \%$ VSMOW as typical of an ice-free world (Shackleton and Kennett, 1975), vary between 18 and $27^{\circ} \mathrm{C}$ (Fig. 6). Two oulier data points from the uppermost part of the Skorków Lumachelle (Divisum Zone) translate into lower temperatures of $14-16^{\circ} \mathrm{C}$. Temperatures calculated for the Upper Platy Limestones and the Top Shales (the Divisum-Mutabilis zone boundary) range from 21 to $27^{\circ} \mathrm{C}$.

Most of the calculated average water temperatures seem to be overestimated taking into account the palaeolatitude $\left(38^{\circ} \mathrm{N}\right)$ of central Poland in the Kimmeridgian (cf. van Hinsbergen et al., 2015) as well as the Late Jurassic palaeoclimatic model of Sellwood and Valdes (2008) and the Early Kimmeridgian temperature $\left(\sim 24^{\circ} \mathrm{C}\right)$ reconstructed for tropical regions (Alberti et al., 2017). The assumption of a mean Kimmeridgian surface temperature of $\sim 18^{\circ} \mathrm{C}$ inferred for the area of present-day Poland after Sellwood and Valdes (2008) allows estimation of the original $\delta^{18} \mathrm{O}_{\text {water }}$ values. Although temperature usually drops downwards in the water column (cf. Manca et al., 2004), freshwater influx occurs more often in very shallow environments, where the thermal stratification is negligible. The measured range of bivalve $\delta^{18} \mathrm{O}$ values $\left(-3.5\right.$ to $-0.6 \%$ ) translates into $\delta^{18} \mathrm{O}_{\text {water }}$ values from -3.0 to $-0.1 \%$ VSMOW using the palaeotemperature equation of Friedman and O'Neil (1977). Water salinity $\left(\mathrm{S}_{\text {water }}\right)$ can, in turn, be calculated on the basis of the universal marine salinity- $\delta^{18} \mathrm{O}_{\text {water }}$ relationship of Railsback et al. (1989), which takes into account effects of freshwater runoff [3] and evaporation [4]. The two given equations were used for salinity calculations below and above the normal marine salinity respectively.

$$
\delta^{18} \mathrm{O}_{\text {water }}=\delta^{18} \mathrm{O}_{0}+\Delta_{\mathrm{fw}} / \mathrm{S}_{0} \cdot\left(\mathrm{S}_{\mathrm{water}}-\mathrm{S}_{0}\right)
$$

where: $\delta^{18} \mathrm{O}_{0}$ - average oxygen isotope composition of Jurassic sea water (assumed as $-1 \%$ VSMOW after Shackleton and Kennett, 1975), $\Delta_{\mathrm{fw}}$ - difference between $\delta^{18} \mathrm{O}$ values of average sea water and local meteoric water (assumed as $-6 \%$ VSMOW using the modern relationship between annual mean $\delta^{18} \mathrm{O}$ values of precipitation and surface air temperature; cf. Rozanski et al., 1993), and S $_{0}$ - average sea water salinity (assumed as 34\%o after Railsback et al., 1989). 
Position, chemical and isotope data of bivalve shells from the Małogoszcz section

\begin{tabular}{|c|c|c|c|c|c|c|c|c|c|c|c|c|}
\hline No. & Taxonomy & Unit & $\begin{array}{c}\text { Position } \\
{[\mathrm{m}]}\end{array}$ & $\begin{array}{c}\text { Position error } \\
{[+/-] \mathrm{m}}\end{array}$ & $\begin{array}{c}\mathrm{Ca} \\
{[\%]}\end{array}$ & $\begin{array}{c}\mathrm{Fe} \\
{[\mathrm{ppm}]}\end{array}$ & $\begin{array}{c}\mathrm{Mg} \\
{[\mathrm{ppm}]}\end{array}$ & $\begin{array}{c}\mathrm{Mn} \\
{[\mathrm{ppm}]}\end{array}$ & $\begin{array}{c}\mathrm{Na} \\
{[\mathrm{ppm}]}\end{array}$ & $\begin{array}{c}\mathrm{Sr} \\
{[\mathrm{ppm}]}\end{array}$ & $\begin{array}{l}\delta^{13} \mathrm{C} \\
{[\% 0]}\end{array}$ & $\begin{array}{l}\delta^{18} \mathrm{O} \\
{[\% \circ]}\end{array}$ \\
\hline M1* & oyster & Top Shales & 206.5 & 1.5 & 38.3 & $596^{*}$ & 333 & 74 & 499 & 617 & - & - \\
\hline M70 & D. delta & Top Shales & 171.3 & 1.2 & 38.4 & 104 & 551 & 17 & 1017 & 709 & 3.62 & -3.35 \\
\hline M59 & D. delta & Top Shales & 171.3 & 1.2 & 39.4 & 114 & 500 & 21 & 796 & 675 & 3.84 & -2.63 \\
\hline M57 & D. delta & Top Shales & 171.3 & 1.2 & 39.1 & 92 & 499 & 18 & 683 & 690 & 4.00 & -2.61 \\
\hline M56 & D. delta & Top Shales & 171.3 & 1.2 & 38.8 & 171 & 486 & 17 & 916 & 642 & 4.02 & -2.23 \\
\hline M54* & D. delta & Top Shales & 171.3 & 1.2 & 36.6 & $509^{*}$ & 1422 & 59 & 629 & 592 & - & - \\
\hline M53 & D. delta & Top Shales & 171.3 & 1.2 & 38.6 & 206 & 553 & 22 & 692 & 653 & 3.94 & -2.47 \\
\hline M52 & D. delta & Top Shales & 171.3 & 1.2 & 38.6 & 152 & 542 & 14 & 886 & 687 & 3.90 & -3.29 \\
\hline M51 & D. delta & Top Shales & 171.3 & 1.2 & 39.2 & 86 & 397 & 10 & 1018 & 694 & 4.04 & -2.84 \\
\hline M36 & D. delta & Top Shales & 171.3 & 1.2 & 39.5 & 71 & 421 & 18 & 751 & 658 & 4.02 & -2.67 \\
\hline M35 & D. delta & Top Shales & 171.3 & 1.2 & 39.8 & 74 & 429 & 10 & 651 & 631 & 3.79 & -2.41 \\
\hline M33 & D. delta & Top Shales & 171.3 & 1.2 & 39.5 & 112 & 489 & 27 & 707 & 711 & 4.18 & -2.38 \\
\hline M15 & D. delta & Top Shales & 171.3 & 1.2 & 39.7 & 77 & 443 & 19 & 734 & 636 & 3.85 & -2.73 \\
\hline M7 & Trichites & Up. Platy Ls & 155 & 3 & 37.7 & 71 & 419 & 14 & 1018 & 721 & 3.66 & -2.50 \\
\hline M69 & oyster & Skork. Lum. & 121 & 1.2 & 39.1 & 109 & 797 & 5 & 548 & 649 & 2.98 & -0.57 \\
\hline M9 & oyster & Skork. Lum. & 121 & 1.2 & 39.4 & 38 & 569 & 1 & 399 & 684 & 3.15 & -1.05 \\
\hline M73* & oyster & Skork. Lum. & 104.8 & 1.3 & 38.7 & $464^{*}$ & 2920 & 17 & 1483 & 860 & - & - \\
\hline M65* & Trichites & Skork. Lum. & 104.8 & 1.3 & 38.7 & $253^{*}$ & 1723 & 6 & 2028 & 729 & - & - \\
\hline M61* & Actinostreon & Skork. Lum. & 104.8 & 1.3 & 38.5 & $558^{*}$ & 1896 & 24 & 555 & 650 & - & - \\
\hline M31 & Trichites & Skork. Lum. & 104.8 & 1.3 & 38.6 & 195 & 1679 & 5 & 2321 & 786 & 3.96 & -2.94 \\
\hline M28 & Trichites & Skork. Lum. & 104.8 & 1.3 & 39.2 & 119 & 1664 & 4 & 2405 & 819 & 3.94 & -2.81 \\
\hline M25 & Trichites & Skork. Lum. & 104.8 & 1.3 & 38.6 & 120 & 1578 & 5 & 2374 & 740 & 3.03 & -1.66 \\
\hline M24 & Trichites & Skork. Lum. & 104.8 & 1.3 & 38.7 & 73 & 1678 & 2 & 2308 & 792 & 3.64 & -2.68 \\
\hline M21 & Trichites & Skork. Lum. & 104.8 & 1.3 & 39.3 & 120 & 1551 & 4 & 2362 & 776 & 3.74 & -2.78 \\
\hline M20 & Trichites & Skork. Lum. & 104.8 & 1.3 & 38.5 & 74 & 1702 & 2 & 2167 & 721 & 3.22 & -1.49 \\
\hline M17 & Trichites & Skork. Lum. & 104.8 & 1.3 & 39.3 & 192 & 1528 & 6 & 2368 & 769 & 3.90 & -3.13 \\
\hline M12 & Trichites & Skork. Lum. & 104.8 & 1.3 & 38.7 & 61 & 1371 & 1 & 2495 & 740 & 3.24 & -2.47 \\
\hline M5 & Trichites & Skork. Lum. & 104.8 & 1.3 & 38.7 & 121 & 1690 & 3 & 2232 & 756 & 3.46 & -1.82 \\
\hline M3 & Trichites & Skork. Lum. & 104.8 & 1.3 & 38.7 & 47 & 1779 & 2 & 2256 & 715 & 3.67 & -1.47 \\
\hline M2* & oyster & Skork. Lum. & 104.8 & 1.3 & 39.4 & $457^{*}$ & 1427 & 21 & 817 & 637 & - & - \\
\hline M18 & Trichites & Skork. Lum. & 100 & 3.5 & 38.6 & 170 & 1728 & 3 & 2279 & 761 & 3.46 & -1.69 \\
\hline M81 & Trichites & Up. Oolite & 47.5 & 10 & 38.9 & $<20$ & 1305 & $<1$ & 2342 & 688 & 3.28 & -1.69 \\
\hline M80 & Trichites & Up. Oolite & 47.5 & 10 & 35.5 & $<20$ & 1246 & 1 & 1834 & 690 & 2.97 & -3.21 \\
\hline M50 & oyster & Up. Oolite & 47.5 & 10 & 38.9 & 25 & 586 & 2 & 234 & 715 & 3.11 & -1.62 \\
\hline M48 & Trichites & Up. Oolite & 47.5 & 10 & 38.6 & $<20$ & 1284 & $<1$ & 2568 & 805 & 3.39 & -2.68 \\
\hline M47 & Trichites & Up. Oolite & 47.5 & 10 & 39.3 & $<20$ & 1467 & 5 & 1928 & 734 & 2.60 & -2.95 \\
\hline M44 & Trichites & Up. Oolite & 47.5 & 10 & 39.4 & $<20$ & 1273 & 2 & 1315 & 761 & 2.99 & -3.46 \\
\hline M77 & Trichites & Up. Oolite & 40 & 2.5 & 37.9 & $<20$ & 1395 & $<1$ & 2374 & 752 & 3.79 & -3.23 \\
\hline
\end{tabular}

* - altered samples showing elevated Fe concentrations

$$
\delta^{18} \mathrm{O}_{\text {water }}=\delta^{18} \mathrm{O}_{0}+\mathrm{m}_{0} \cdot\left(\mathrm{S}_{\mathrm{water}}-\mathrm{S}_{0}\right)
$$

where: $m_{0}$ - evaporative enrichment parameter being the relation between $\delta^{18} \mathrm{O}$ and salinity observed in evaporative basins (assumed as $0.35 \%$ VSMOW per 1 salinity per mil according to Railsback et al., 1989), and other symbols are the same as in eq. [2].

The calculated sea water $\delta^{18} \mathrm{O}$ values translate into a salinity range of 21 to $37 \%$. Although the modelling does not allow for possible changes in depth of the basin and temporal climate fluctuations, it points to the possibility of occurrence of episodes of decreased salinity in the basin studied. Low and variable $\delta^{18} \mathrm{O}$ values of Lower Kimmeridgian-lowermost Upper
Kimmeridgian fossils from the SW margin of the Holy Cross Mountains may be regarded as a manifestation of major shallowing of the epicratonic Polish basin, being an effect of prolonged marine regression, which is well-documented starting from the Upper Oxfordian (cf. Matyja, 1977, 2011; Kutek, 1994; Matyja et al., 2006; Matyja and Wierzbowski, 2014; Wierzbowski, 2017). The bathymetry and salinity changes connected with this sea level fall likely masked subtle climatic and environmental fluctuations in central Poland. Although some authors have postulated the presence of such variations in the Kimmeridgian e.g. a cooling at the Oxfordian-Kimmeridgian transition (Abbink et al., 2001; Zou et al., 2019), a warming of deep sea water at the Early-Late Kimmeridgian transition 


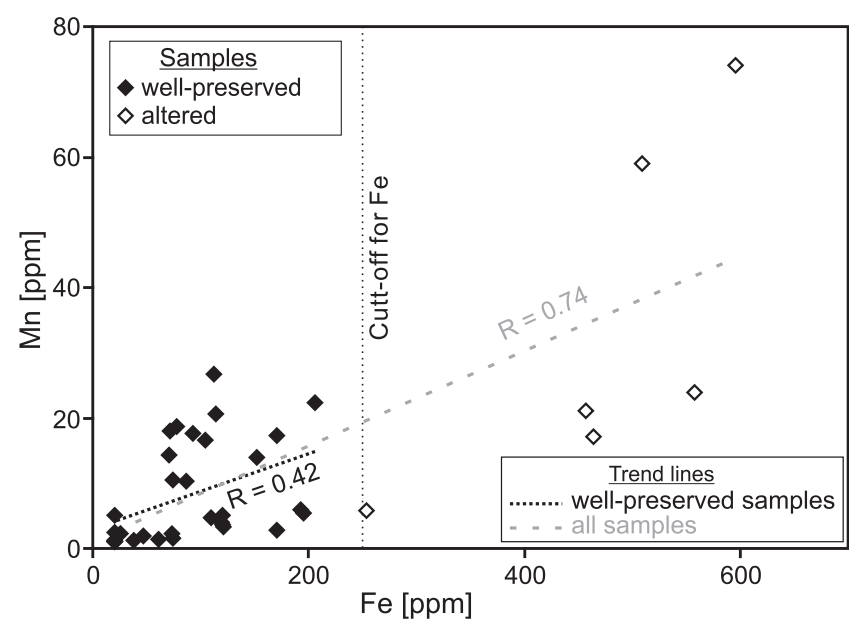

Fig. 8. Cross-plot of Fe and Mn concentrations in the bivalve shells studied

Cut-off limit of $250 \mathrm{ppm}$ of $\mathrm{Fe}$ is accepted for well-preserved samples; a strong correlation $(R=0.74, p<0.01)$ is observed in the entire dataset, and a moderate one $(R=0.42, p<0.05)$ in well-preserved samples

(Colombié et al., 2018) or a slight warming throughout almost the whole Kimmeridgian (Zuo et al., 2019), they are not observed in the study area (Fig. 6; see also Wierzbowski, 2015).

A gradual decrease in belemnite and brachiopod $\delta^{18} \mathrm{O}$ values (from $\sim 0$ to $\sim 1 \%$ o VPDB) is observed in central Poland throughout the Oxfordian (Wierzbowski, 2015). This decrease is attributed to a temperature rise and/or increased freshwater runoff during the onset of the marine regression. The oxygen and carbon isotope values of Lower Kimmeridgian bivalves from central Poland ( -3.5 to $-0.6 \%$, and 2.6 to $4.2 \%$, respectively) are comparable to those from shallow-marine facies of the Paris Basin, Burgundy, the Jura Mountains, and the Lower Saxony basin (cf. Brigaud et al., 2008; Lathuilière et al., 2015; Colombié et al., 2018; Zuo et al., 2019). Low $\delta^{18} \mathrm{O}$ values of Lower Kimmeridgian fossils from western Europe are likely related to shallowing of epicontinental marine basins. A similar phenomenon and a salinity-related decrease is also reported for the Early Kimmeridgian basin of the Russian Platform (Wierzbowski et al., 2018). Salinity and thermobathymetry effects on fossil $\delta^{18} \mathrm{O}$ values at European localities may also be an alternative explanation of such phenomena as weak latitudinal temperature gradients or thermal homogenization of sea water postulated for the Kimmeridgian (see Alberti et al., 2017; Colombié et al., 2018).

Higher $\delta^{18} \mathrm{O}$ values ( -0.5 to $0.5 \%$ ) are reported again for the mid-Tithonian oysters from central Poland (Wierzbowski et al., 2016). The mid-Tithonian fossils are derived from open marine deposits belonging to the Pałuki Formation and the lowermost part of the Kcynia Formation (Dembowska, 1979; Kutek and Zeiss, 1997; Matyja and Wierzbowski, 2016; Wierzbowski et al., 2016). This may be related to a successive deepening of the mid-Polish sedimentary basin during a Late Kimmeridgian transgression, which began in the Eudoxus Chron (cf. Kutek, 1994; Matyja and Wierzbowski, 2014; Wierzbowski, 2017). All the data show that the Upper Jurassic oxygen isotope record of central Poland was mainly controlled by sea level changes.

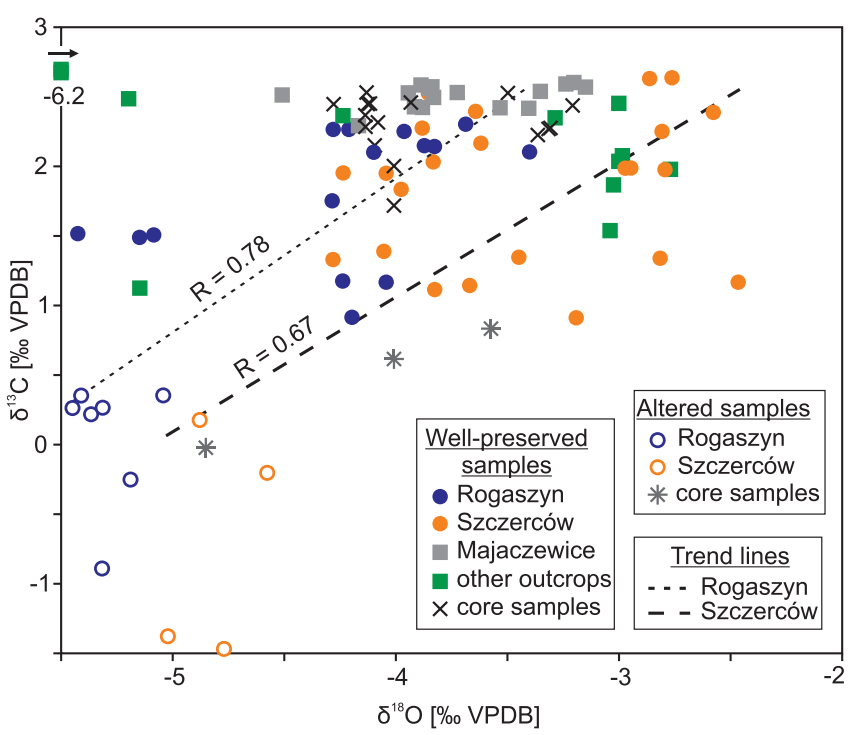

Fig. 9. Cross-plot of $\delta^{13} \mathrm{C}$ versus $\delta^{18} \mathrm{O}$ values of bulk carbonates from the Lower Kimmeridgian sections studied

Strong and statistically significant correlations between $\delta^{18} \mathrm{O}$ and $\delta^{13} \mathrm{C}$ values are observed in the Rogaszyn $(R=0.78, p<0.01)$ and Szczerców $(R=0.67, p<0.01)$ datasets

\section{CARBON ISOTOPE RECORD OF BULK CARBONATES}

The bulk rocks studied are derived from deeper parts of the Kimmeridgian basin of central Poland i.e. the Wieluń Upland, its northern vicinity and the Radomsko elevation. Low $\delta^{13} \mathrm{C}$ values of bulk carbonates (-1.5 to $0.4 \%$ ) are observed within the highly weathered and abandoned upper part of the Rogaszyn section, and porous oolitic limestones from the Szczerców section (Figs. 3 and 5$)$. A low $\delta^{13} \mathrm{C}$ value $(0.3 \%$ ) is also observed in proximity to the oncolite layer in the lower part of the Rogaszyn Quarry. Strong correlation observed between $\delta^{13} \mathrm{C}$ and $\delta^{18} \mathrm{O}$ values from these localities (Fig. 9) may be linked to the postdepositional equilibration of rocks, sensitive to diagenesis, with meteoric waters in the subsurface vadose or phreatic zone (cf. Jenkyns and Clayton, 1986; Banner and Hanson, 1990; Marshall, 1992; Huck et al., 2013; Jach et al., 2014; Swart and Oehlert, 2018). Since other parts of the sections studied show more stable $\delta^{13} \mathrm{C}$ values (0.9 to $2.6 \%$ ), which are not noticeably correlated with $\delta^{18} \mathrm{O}$ values (Fig. 9), one can assume that their original marine carbon isotope composition is still preserved. Moderately scattered $\delta^{13} \mathrm{C}$ values $(0.0$ to 2.6$)$ are observed within borehole core samples (Fig. 9). The majority of these samples have, however, high $\delta^{13} \mathrm{C}$ values (above $0.9 \%$ ) and no correlation between their $\delta^{18} \mathrm{O}$ and $\delta^{13} \mathrm{C}$ values is observed. Distinctly lower $\delta^{13} \mathrm{C}$ values (0.0 to $0.8 \%$ ) are seen in only three samples from a narrow interval $(66.8-72.0 \mathrm{~m})$ of a borehole core 6W (Table 2; see also Wierzbowski, 2017). As coeval samples from other borehole cores and the Majaczewice section show much higher $\delta^{13} \mathrm{C}$ values (Fig. 10) this interval of the core $6 \mathrm{~W}$ is interpreted as diagenetically altered. 
Stratigraphical and isotope data of bulk-carbonates

\begin{tabular}{|c|c|c|c|c|c|c|c|c|}
\hline No. & Lithology & Outcrop & Bed/depth & Zone & Subzone & $\begin{array}{l}\text { Position in } \\
\text { subzone }\end{array}$ & $\delta^{13} \mathrm{C}[\% 0]$ & $\delta^{18} \mathrm{O}[\% 0]$ \\
\hline KL 66 & Is & Majaczewice & 13 & Hypselocyclum & Lothari & 0.20 & 2.43 & -3.92 \\
\hline $\mathrm{KL} 76$ & Is & Majaczewice & 13 & Hypselocyclum & Lothari & 0.20 & 2.29 & -4.17 \\
\hline $\mathrm{KL} 71$ & Is & Majaczewice & 13 & Hypselocyclum & Lothari & 0.20 & 2.42 & -3.53 \\
\hline $\mathrm{KL} 74$ & $\mathrm{mrl}$ & Majaczewice & 12 & Hypselocyclum & Lothari & 0.19 & 2.50 & -3.83 \\
\hline KL 63 & Is & Majaczewice & 11 & Hypselocyclum & Lothari & 0.18 & 2.42 & -3.40 \\
\hline KL 61 & $\mathrm{mrl}$ & Majaczewice & 10 & Hypselocyclum & Lothari & 0.16 & 2.42 & -3.88 \\
\hline $\mathrm{KL} 60$ & Is & Majaczewice & 9 & Hypselocyclum & Lothari & 0.15 & 2.57 & -3.15 \\
\hline KL 86 & $\mathrm{mrl}$ & Majaczewice & 8 & Hypselocyclum & Lothari & 0.13 & 2.51 & -4.51 \\
\hline $\mathrm{KL} 78$ & Is & Majaczewice & 7 & Hypselocyclum & Lothari & 0.12 & 2.54 & -3.35 \\
\hline KL 62 & $\mathrm{mrl}$ & Majaczewice & 6 & Hypselocyclum & Lothari & 0.10 & 2.53 & -3.94 \\
\hline KL 65 & Is & Majaczewice & 5 & Hypselocyclum & Lothari & 0.07 & 2.60 & -3.20 \\
\hline $\mathrm{KL} 77$ & $\mathrm{mrl}$ & Majaczewice & 4 & Hypselocyclum & Lothari & 0.06 & 2.57 & -3.84 \\
\hline KL 59 & Is & Majaczewice & 3 & Hypselocyclum & Lothari & 0.04 & 2.59 & -3.24 \\
\hline KL 84 & $\mathrm{mrl}$ & Majaczewice & 2 & Hypselocyclum & Lothari & 0.03 & 2.56 & -3.85 \\
\hline KL 80 & $\mathrm{mrl}$ & Majaczewice & 2 & Hypselocyclum & Lothari & 0.02 & 2.58 & -3.89 \\
\hline $\mathrm{KL} 72$ & Is & Majaczewice & 1 & Hypselocyclum & Lothari & 0.01 & 2.53 & -3.73 \\
\hline $\mathrm{KL} 1$ & Is & Szczerców & 6 & Hypselocyclum & Lothari & 0.04 & 1.83 & -3.98 \\
\hline KL 24 & Is & Szczerców & 5 & Hypselocyclum & Hippolytense & 0.98 & 2.28 & -3.88 \\
\hline $\mathrm{KL} 25$ & Is & Szczerców & 5 & Hypselocyclum & Hippolytense & 0.98 & 2.40 & -3.64 \\
\hline KL 23 & Is & Szczerców & 5 & Hypselocyclum & Hippolytense & 0.98 & 2.17 & -3.62 \\
\hline $\mathrm{KL} 10$ & Is & Szczerców & 5 & Hypselocyclum & Hippolytense & 0.96 & 1.95 & -4.24 \\
\hline KL6 & Is & Szczerców & 5 & Hypselocyclum & Hippolytense & 0.91 & 1.33 & -4.28 \\
\hline $\mathrm{KL} 15$ & Is & Szczerców & 5 & Hypselocyclum & Hippolytense & 0.90 & 1.95 & -4.04 \\
\hline $\mathrm{KL} 4$ & Is & Szczerców & 5 & Hypselocyclum & Hippolytense & 0.86 & 1.39 & -4.05 \\
\hline $\mathrm{KL} 11^{*}$ & ool Is & Szczerców & 4 & Hypselocyclum & Hippolytense & 0.83 & $-0.20^{*}$ & $-4.58^{*}$ \\
\hline $\mathrm{KL} 8^{*}$ & ool Is & Szczerców & 4 & Hypselocyclum & Hippolytense & 0.79 & $0.18^{*}$ & $-4.88^{*}$ \\
\hline $\mathrm{KL} 5^{*}$ & ool Is & Szczerców & $3 b$ & Hypselocyclum & Hippolytense & 0.67 & $-1.38^{*}$ & $-5.02^{*}$ \\
\hline KL 50* & ool Is & Szczerców & $3 b$ & Hypselocyclum & Hippolytense & 0.64 & $-1.47^{*}$ & $-4.77^{*}$ \\
\hline KL 19 & Is & Szczerców & $3 a$ & Hypselocyclum & Hippolytense & 0.63 & 1.35 & -3.45 \\
\hline $\mathrm{KL} 12$ & Is & Szczerców & $3 a$ & Hypselocyclum & Hippolytense & 0.60 & 2.25 & -2.81 \\
\hline $\mathrm{KL} 22$ & Is/mrl & Szczerców & 2 & Hypselocyclum & Hippolytense & 0.58 & 2.63 & -2.86 \\
\hline $\mathrm{KL} 3$ & Is/mrl & Szczerców & 2 & Hypselocyclum & Hippolytense & 0.56 & 2.64 & -2.76 \\
\hline $\mathrm{KL} 20$ & Is $/ \mathrm{mrl}$ & Szczerców & 2 & Hypselocyclum & Hippolytense & 0.55 & 1.99 & -2.97 \\
\hline KL 21 & Is $/ \mathrm{mrl}$ & Szczerców & 2 & Hypselocyclum & Hippolytense & 0.53 & 1.98 & -2.79 \\
\hline $\mathrm{KL} 13$ & $\mathrm{mrl} \mathrm{cl}$ & Szczerców & 1 & Hypselocyclum & Hippolytense & 0.50 & 1.34 & -2.82 \\
\hline $\mathrm{KL} 17$ & $\mathrm{mrl} \mathrm{cl}$ & Szczerców & 1 & Hypselocyclum & Hippolytense & 0.49 & 1.17 & -2.47 \\
\hline $\mathrm{KL} 16$ & $\mathrm{mrl} \mathrm{cl}$ & Szczerców & 0 & Hypselocyclum & Hippolytense & 0.40 & 0.91 & -3.19 \\
\hline $\mathrm{KL} 7$ & $\mathrm{mrl} \mathrm{cl}$ & Szczerców & 0 & Hypselocyclum & Hippolytense & 0.36 & 2.39 & -2.58 \\
\hline $\mathrm{KL} 2$ & $\mathrm{mrl} \mathrm{cl}$ & Szczerców & 0 & Hypselocyclum & Hippolytense & 0.23 & 1.14 & -3.67 \\
\hline KL9 & $\mathrm{mrl} \mathrm{cl}$ & Szczerców & 0 & Hypselocyclum & Hippolytense & 0.20 & 1.11 & -3.83 \\
\hline $\mathrm{KL} 18$ & $\mathrm{mrl} \mathrm{cl}$ & Szczerców & 0 & Hypselocyclum & Hippolytense & 0.11 & 1.99 & -2.95 \\
\hline $\mathrm{KL} 14$ & $\mathrm{mrl} \mathrm{cl}$ & Szczerców & 0 & Hypselocyclum & Hippolytense & 0.06 & 2.03 & -3.83 \\
\hline KL 87 & Is & Rogaszyn & $7 / 8$ & Platynota & Guilherandense & 0.99 & 0.91 & -4.20 \\
\hline KL 89* & Is & Rogaszyn & $7 / 8$ & Platynota & Guilherandense & 0.96 & $-0.25^{*}$ & $-5.19^{*}$ \\
\hline KL 93* & Is & Rogaszyn & $7 / 8$ & Platynota & Guilherandense & 0.95 & $0.22^{*}$ & $-5.37^{*}$ \\
\hline KL 94* & Is & Rogaszyn & $7 / 8$ & Platynota & Guilherandense & 0.89 & $0.35^{*}$ & $-5.04^{*}$ \\
\hline KL 88* & Is & Rogaszyn & $7 / 8$ & Platynota & Guilherandense & 0.82 & $0.35^{*}$ & $-5.41^{*}$ \\
\hline KL 92* & Is & Rogaszyn & $7 / 8$ & Platynota & Guilherandense & 0.75 & $0.26^{*}$ & $-5.45^{*}$ \\
\hline KL 91* & Is & Rogaszyn & $7 / 8$ & Platynota & Guilherandense & 0.68 & $-0.89^{*}$ & $-5.32^{*}$ \\
\hline KL 53 & Is & Rogaszyn & $7 / 8$ & Platynota & Guilherandense & 0.65 & 2.10 & -3.40 \\
\hline KL 83 & Is & Rogaszyn & 5 & Platynota & Guilherandense & 0.57 & 2.30 & -3.69 \\
\hline $\mathrm{KL} 75$ & Is & Rogaszyn & 5 & Platynota & Guilherandense & 0.55 & 2.14 & -3.83 \\
\hline
\end{tabular}


Tab. 2 cont.

\begin{tabular}{|c|c|c|c|c|c|c|c|c|}
\hline No. & Lithology & Outcrop & Bed/depth & Zone & Subzone & $\begin{array}{l}\text { Position in } \\
\text { subzone }\end{array}$ & $\delta^{13} \mathrm{C}[\% \circ]$ & $\delta^{18} \mathrm{O}[\% \circ]$ \\
\hline KL 52 & Is & Rogaszyn & 5 & Platynota & Guilherandense & 0.50 & 2.27 & -4.28 \\
\hline $\mathrm{KL} 73$ & Is & Rogaszyn & 5 & Platynota & Guilherandense & 0.46 & 2.15 & -3.87 \\
\hline KL 54 & Is & Rogaszyn & 5 & Platynota & Guilherandense & 0.42 & 2.25 & -3.96 \\
\hline KL 85 & $\mathrm{mrl}$ & Rogaszyn & 4 & Platynota & Guilherandense & 0.40 & 1.17 & -4.04 \\
\hline KL 51 & $\mathrm{mrl}$ & Rogaszyn & 4 & Platynota & Guilherandense & 0.29 & 1.18 & -4.24 \\
\hline KL 82 & Is & Rogaszyn & 3 & Platynota & Guilherandense & 0.23 & 2.27 & -4.21 \\
\hline KL 69 & Is & Rogaszyn & 3 & Platynota & Guilherandense & 0.18 & 2.10 & -4.10 \\
\hline KL 79 & Is & Rogaszyn & 3 & Platynota & Guilherandense & 0.09 & 2.53 & -3.85 \\
\hline $\mathrm{KL} \mathrm{64*}$ & $\mathrm{mrl} \mathrm{cl}$ & Rogaszyn & 2 & Platynota & Guilherandense & 0.04 & $0.26^{*}$ & $-5.31^{*}$ \\
\hline $\mathrm{KL} 68$ & Is & Rogaszyn & 1 & Platynota & Desmoides & 0.97 & 1.51 & -5.09 \\
\hline KL 67 & Is & Rogaszyn & 1 & Platynota & Desmoides & 0.82 & 1.49 & -5.15 \\
\hline KL 81 & Is & Rogaszyn & 1 & Platynota & Desmoides & 0.45 & 1.52 & -5.43 \\
\hline $\mathrm{KL} 70$ & Is & Rogaszyn & 1 & Platynota & Desmoides & 0.19 & 1.75 & -4.29 \\
\hline KL 34 & $\mathrm{mrl}$ & core $37 / 13.5$ & $(69 \mathrm{~m})$ & Hypselocyclum & Lothari & 0.69 & 1.72 & -4.01 \\
\hline $\mathrm{KL} 33$ & $\mathrm{mrl}$ & core PD20B & $(175-176 \mathrm{~m})$ & Hypselocyclum & Lothari & 0.55 & 2.32 & -4.08 \\
\hline KL 35 & $\mathrm{mrl}$ & core 130SP & $(127-137 \mathrm{~m})$ & Hypselocyclum & Lothari & 0.54 & 2.37 & -4.14 \\
\hline KL 29 & Is & core PW408 & $(149.5 \mathrm{~m})$ & Hypselocyclum & Lothari & 0.53 & 2.44 & -3.21 \\
\hline $\mathrm{KL} 27$ & Is & core PW408 & $(149.5 \mathrm{~m})$ & Hypselocyclum & Lothari & 0.53 & 2.45 & -4.12 \\
\hline KL 31 & Is & core PW408 & $(150 \mathrm{~m})$ & Hypselocyclum & Lothari & 0.52 & 2.45 & -4.28 \\
\hline $\mathrm{KL} 30$ & Is & core PW408 & $(152.6 \mathrm{~m})$ & Hypselocyclum & Lothari & 0.51 & 2.45 & -4.13 \\
\hline $\mathrm{KL} 32$ & Is & core $37 / 13.5$ & $(81 \mathrm{~m})$ & Hypselocyclum & Lothari & 0.5 & 2.23 & -3.36 \\
\hline $\mathrm{KL} 36$ & Is & core $37 / 13.5$ & $(83 \mathrm{~m})$ & Hypselocyclum & Lothari & 0.49 & 2.00 & -4.01 \\
\hline $\mathrm{KL} 28$ & Is & core KT109 & $(256.5 \mathrm{~m})$ & Hypselocyclum & Lothari & 0.37 & 2.28 & -4.14 \\
\hline KL 26 & Is & core 130SP & $(173 \mathrm{~m})$ & Hypselocyclum & Lothari & 0.17 & 2.27 & -3.32 \\
\hline $\mathrm{KL} \mathrm{40*}$ & $\mathrm{mrl}$ & core $6 \mathrm{~W}$ & $(66.8-68.1 \mathrm{~m})$ & Hypselocyclum & Lothari & 0.16 & $-0.02^{*}$ & $-4.85^{\star}$ \\
\hline $\mathrm{KL} \mathrm{43*}$ & $\mathrm{mrl}$ & core $6 \mathrm{~W}$ & $(66.8-68.1 \mathrm{~m})$ & Hypselocyclum & Lothari & 0.15 & $0.62^{*}$ & $-4.01^{*}$ \\
\hline $\mathrm{KL} \mathrm{44^{* }}$ & $\mathrm{mrl}$ & core $6 \mathrm{~W}$ & $(68.1-72.0 \mathrm{~m})$ & Hypselocyclum & Lothari & 0.14 & $0.83^{*}$ & $-3.57^{*}$ \\
\hline KL 46 & Is & core KP2 & $(103.2-103.6 \mathrm{~m})$ & Hypselocyclum & Lothari & 0.1 & 2.15 & -4.09 \\
\hline KL 45 & Is & core KP2 & $(113.7-115 \mathrm{~m})$ & Hypselocyclum & Lothari & 0.07 & 2.28 & -3.31 \\
\hline $\mathrm{KL} 48$ & Is & core KP3 & $(116-117 \mathrm{~m})$ & Hypselocyclum & Lothari & 0.02 & 2.46 & -3.93 \\
\hline KL 49 & Is & core KP2 & $(117 \mathrm{~m})$ & Hypselocyclum & Lothari & 0 & 2.53 & -3.50 \\
\hline $\mathrm{KL} 47$ & Is & core $\mathrm{KP} 2$ & $(117-118 \mathrm{~m})$ & Hypselocyclum & Hippolytense & 0.98 & 2.53 & -4.13 \\
\hline KL 97 & Is & Góry Wapienne & - & Acanthicum & - & 0.25 & 1.54 & -3.05 \\
\hline KL 90 & Is & Góry Wapienne & - & Acanthicum & - & 0.25 & 1.87 & -3.02 \\
\hline KL 95 & Is & Burzenin 47 & - & Divisum & Uhlandi & 0.5 & 2.04 & -3.01 \\
\hline KL 39 & Is & Burzenin 47 & - & Divisum & Uhlandi & 0.5 & 1.98 & -2.77 \\
\hline KL 98 & Is & Sarnów & - & Divisum & Crussoliense & 0.5 & 2.46 & -3.01 \\
\hline KL 58 & Is & Sarnów & - & Divisum & Crussoliense & 0.5 & 2.35 & -3.29 \\
\hline $\mathrm{KL} 38$ & Is & Burzenin 16/9 & - & Hypselocyclum & Lothari & 0.9 & 2.08 & -2.99 \\
\hline KL 37 & Is & Burzenin 16/2 & - & Hypselocyclum & Lothari & 0.75 & 2.49 & -5.20 \\
\hline KL 41 & Is & Kule 84 & - & Hypselocyclum & Hippolytense & 0.25 & 1.13 & -5.15 \\
\hline $\mathrm{KL} 42$ & Is & Kule 84 & - & Hypselocyclum & Hippolytense & 0.25 & 2.36 & -4.24 \\
\hline KL 96 & $\mathrm{mrl}$ & PJ110 & - & Planula & Planula & 0.95 & 2.68 & -6.72 \\
\hline KL 55 & $\mathrm{mrl}$ & PJ110 & - & Planula & Planula & 0.95 & 2.70 & -6.16 \\
\hline
\end{tabular}

* - altered samples (see text); position in subzone - percentage position in a stratigraphical subzone, Is - limestone, ool ls - oolitic limestone, $\mathrm{mrl}$ - marl, $\mathrm{mrl} \mathrm{cl}$ - marly clay

Although bulk carbonate $\delta^{13} \mathrm{C}$ values, which are considered as well-preserved, show some scatter, a gentle, long-term decreasing trend of the values is observed (Fig. 10). A similar decrease in $\delta^{13} \mathrm{C}$ values of marine carbonates and belemnite rostra is also noted from western Europe (Colombié et al., 2011; 2018) and the Russian Platform (Riboulleau et al., 1998; Zakharov et al., 2005; Wierzbowski et al., 2013, 2018; see Fig.
10). Absolute $\delta^{13} \mathrm{C}$ values of an "upper envelope" of the current dataset are similar to coeval bulk carbonate data from $\mathrm{W}$ France, W Switzerland, central Germany and the Tatra Mountains (Colombié et al., 2011, 2018; Jach et al., 2014; Zuo et al., 2018). This indicates that the Kimmeridgian global trend of decreasing carbon isotope values (cf. Price et al., 2016; Zuo et al., 2018) and marine carbon isotope signatures are, at least partly, 

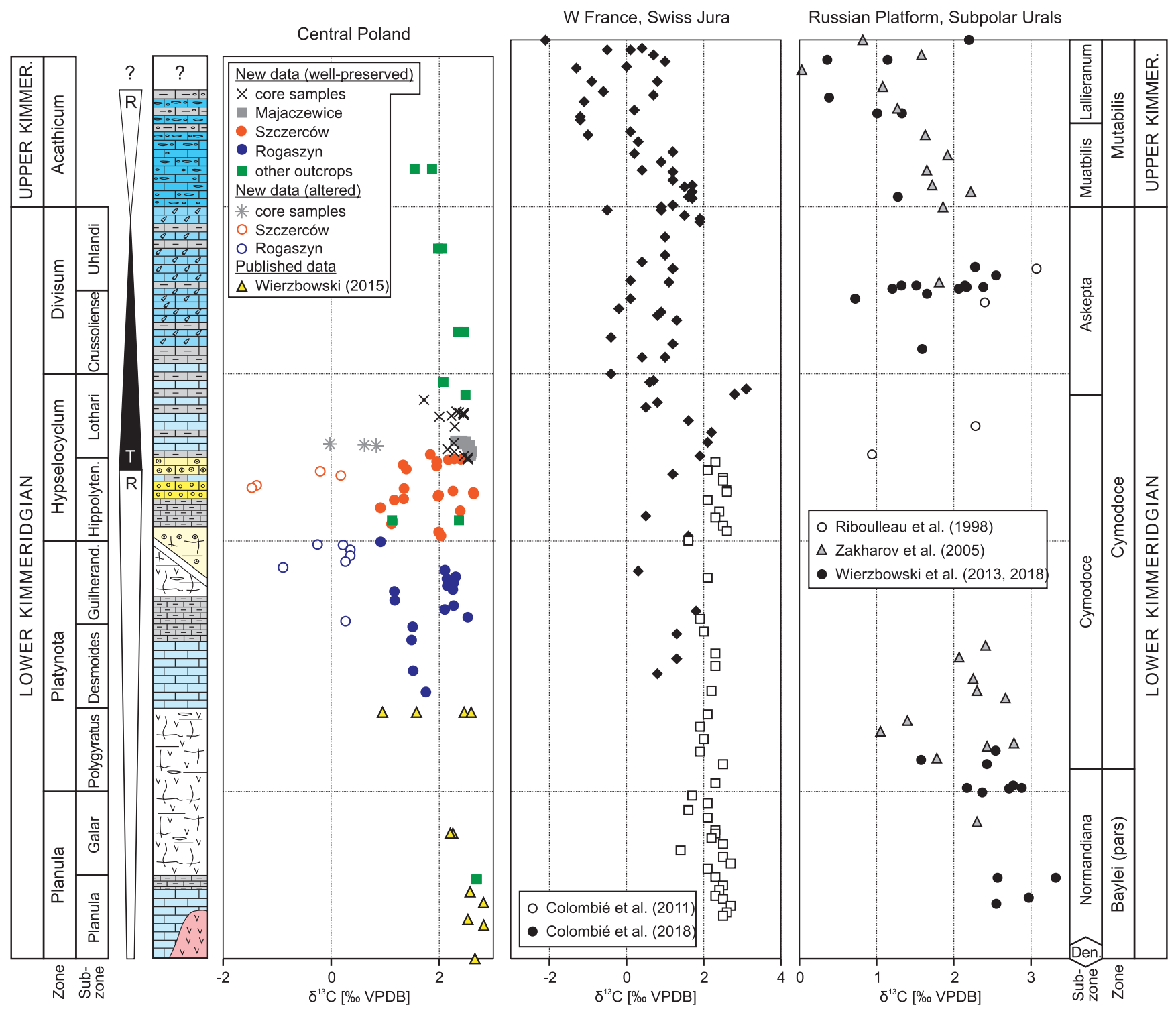

Fig. 10. Bulk carbonate $\delta^{13} \mathrm{C}$ record of central Poland (present and Wierzbowski's 2015 data), and its comparison with the bulk carbonate record of western Europe (after Colombié et al., 2011, 2018) and belemnite data from the Russian Platform and Subpolar Urals (after Riboulleau et al., 1998; Zakharov et al., 2005; Wierzbowski et al., 2013, 2018)

Stratigraphical correlations between regional zonal schemes are established after Wierzbowski and Rogov (2013), Wierzbowski et al. (2013), and Comment et al. (2015). Generalized lithological and major sequence logs for the Wieluń Upland (Planula to Platynota-Hypselocyclum zone boundary) and its northern vicinity (Platynota-Hypselocyclum zone boundary to Acanthicum Zone) are given after Wierzbowski (2017); the vertical scale of the diagram is based on the biostratigraphical zonal scheme and does not reflect variable thickness of the strata. Lithological symbols as in Figure 2

recorded in central Poland. Local effects connected with freshwater inflow and water-mass ageing in a very shallow environment probably caused negative shifts within some carbon isotope data of bulk carbonates (Fig. 10). The negative carbon isotope shifts are mostly confined to very shallow, lowstand deposits of the Prusicko and "oolitic" formations encompassing the upper Platynota and the lower Hypselocyclum zones. Similar $\delta^{13} \mathrm{C}$ values of adjoining limestone and marly beds indicates that environmental factors driving contents of carbonate and clastic material are not recorded in the carbon isotope signatures of the rocks. This may be due to a weak relationship between short-term changes in depositional conditions and the carbon isotope composition of DIC of the whole basin or due to early diagenetic processes, which might have caused carbon isotope homogenisation of neighbouring beds.

\section{CONCLUSIONS}

Newly presented oxygen and carbon isotope values of well-preserved marine bivalves and bulk carbonates from the Lower-lowermost Upper Kimmeridgian of central Poland have allowed documentation of local environmental changes driven by a major regressive-transgressive cycle. $\delta^{18} \mathrm{O}$ and $\delta^{13} \mathrm{C}$ values of bivalve shells from the Małogoszcz section (SW margin of the Holy Cross Mountains), which were deposited in an extremely shallow environment during the Hypselocyclum and the earliest Divisum chrons, show significant scatter because of salinity variations and water-mass ageing. Calculated oxygen isotope temperatures (between 18 and $27^{\circ} \mathrm{C}$ ) may be partly overestimated as a result of decreases in the salinity of 
the basin. Partial stabilization of the isotope signatures is noted after the marine transgression, in the lowermost Mutabilis Zone.

Although a global, gentle decrease in marine $\delta^{13} \mathrm{C}$ values throughout the Kimmeridgian is recorded in bulk carbonate data from central Poland (on the Radomsko Elevation and the Wieluń Upland), numerous, low $\delta^{13} \mathrm{C}$ values are found in the interval of maximal shallowing of the basin, which took place during the late Platynota and early Hypselocyclum chrons.

Newly obtained oxygen isotope data of well-preserved fossils, along with published $\delta^{18} \mathrm{O}$ values of Wierzbowski (2015), and Wierzbowski et al. (2016), may be used to document tem- perature and salinity variations in the epicontinental Polish basin during the major Late Oxfordian-earliest Kimmeridgian regression and the consecutive transgressions, which started, depending on the location, in the latest Hypselocyclum or the Divisum chrons of the latest Early Kimmeridgian. The present and published data suggest that $\delta^{18} \mathrm{O}$ values of Upper Jurassic fossils from central Poland correspond closely to sea level variations.

Acknowledgements. This study was supported by the National Science Centre, Poland (grant no. 2014/13/B/ST10/02511). Two anonymous reviewers are thanked for constructive comments are suggested improvements.

\section{REFERENCES}

Anderson, T.F., Arthur, M.A., 1983. Stable isotopes of oxygen and carbon and their application to sedimentologic and paleoenvironmental problems. In: Stable Isotopes in Sedimentary Geology (eds. M.A. Arthur, T.F. Anderson, I.R. Kaplan, J. Veizer and L.S. Land): 1-1-1-151. SEPM Short Course No. 10, Dallas.

Abbink, O., Targarona, J., Brinkhuis, H., Visscher, H., 2001. Late Jurassic to earliest Cretaceous palaeoclimatic evolution of the southern North Sea. Global and Planetary Change, 30: 231-256.

Alberti, M., Fürsich., F.T., Abdelhady, A.A., Andersen, N., 2017 Middle to Late Jurassic equatorial seawater temperatures and latitudinal temperature gradients based on stable isotopes of brachiopods and oysters from Gebel Maghara, Egypt. Palaeogeography, Palaeoclimatology, Palaeoecology, 468: 301-313.

Anderson, T.F., Popp, B.N., Williams, A.C., Ho L.-Z., Hudson, J.D., 1994. The stable isotopic records of fossils from the Peterborough Member, Oxford Clay Formation (Jurassic), UK: palaeoenvironmental implications. Journal of the Geological Society, 151: 125-138.

Banner, J.L., Hanson, G.N., 1990. Calculation of simultaneous isotopic and trace element variations during water-rock interaction with applications to carbonate diagenesis. Geochimica Cosmochimca Acta, 54: 3123-3137.

Barbin, V., 2000. Cathodoluminescence of carbonate shells: biochemical vs diagenetic process. In: Cathodoluminescence in Geosciences (eds. M. Pagel, V. Barbin, P. Blanc and D. Ohnenstetter): 303-329. Springer-Verlag, Berlin, Heidelberg.

Barbin, V., 2013. Application of cathodoluminescence microscopy to recent and past biological materials: a decade of progress. Mineralogy and Petrology, 107: 353-362.

Brand, U., Veizer, J., 1980. Chemical diagenesis of a multicomponent carbonate system-1: trace elements. Journal of Sedimentary Petrology, 50: 1219-1236.

Brigaud, B., Pucéat, E., Pellenard, P., Vincent, B., Joachimski, M.M., 2008. Climatic fluctuations and seasonality during the Late Jurassic (Oxfordian-Early Kimmeridgian) inferred from $\delta^{18} \mathrm{O}$ of Paris Basin oyster shells. Earth and Planetary Science Letters, 273: 58-67.

Brigaud, B., Durlet, C., Deconinck, J.-F., Vincent, B., Pucéat, E., Thierry, J., Trouiller, A., 2009. Facies and climate/environmental changes recorded on a carbonate ramp: a sedimentological and geochemical approach on Middle Jurassic carbonates (Paris Basin, France). Sedimentary Geology, 222: 181-206.

Chateigner, D., Morales, M., Harper, E.M., 2002. QTA of prismatic calcite layers of some bivalves, a link to trichite ancestrals. Materials Science Forum, 408-412: 1687-1692.

Colombié, C., Lécuyer, C., Strasser, A., 2011. Carbon- and oxygen-isotope records of palaeoenvironmental and carbonate production changes in shallow-marine carbonates (Kimmeridgian, Swiss Jura). Geological Magazine, 148: 133-153.

Colombié, C., Carcel, D., Lécuyer, C., Ruffel, A., Schnyder, J., 2018. Temperature and cyclone frequency in Kimmeridgian
Greenhouse period (late Jurassic). Global and Planetary Change, 170: 126-145.

Comment, G., Lefort, A., Koppka, J., Hantzpergue, P., 2015. Le Kimméridgien d'Ajoie (Jura, Suisse): lithostratigraphie et biostratigraphie de la Formation de Reuchenette. Revue de Paléobiologie, Genève, 34: 161-194.

Dadlez, R., Marek, S., Pokorski, J., 2000. Geological Map of Poland without Cainozoic Deposits, scale 1:1000 000. Państwowy Instytut Geologiczny, Warszawa.

Dembowska, J., 1979. Systematization of lithostratigraphy of the Upper Jurassic in northern and central Poland (in Polish with English summary). Kwartalnik Geologiczny, 23 (3): 617-630.

Esteban-Delgado, F.J., Harper, E.M., Checa, A.G., Rodríguez-Navarro, A.B., 2008. Origin and expansion of foliated microstructure in pteriomorph bivalves. Biological Bulletin, 214: 153-165.

Friedman, I., O'Neil, J.R., 1977. Compilation of stable isotope fractionation factors of geochemical interest, Data of Geochemistry, 6th edition. Geochemical Survey Professional Paper, 440 - KK: KK1-KK12.

Hong, W., Keppens, E., Nielsen, P., van Riet, A., 1995. Oxygen and carbon isotope study of the Holocene oyster reefs and paleoenvironmental reconstruction on the northwest coast of Bohai Bay, China. Marine Geology, 124: 289-302.

Huck, S., Heimhofer, U., Immenhauser, A., Weissert, H., 2013. Carbon-isotope stratigraphy of Early Cretaceous (Urgonian) shoal-water deposits: diachronous changes in carbonate-platform production in the north-western Tethys. Sedimentary Geology, 290: 157-174.

Imai, N., Terashima, S., Itoh, S., Ando, A., 1996. 1996 compilation of analytical data on nine GSJ geochemical reference samples "Sedimentary rock series". Geostandards Newsletter, 20: 165-216.

Jach, R., Djerić, N., Goričan, Š., Reháková, D., 2014. Integrated stratigraphy of the Middle-Upper Jurassic of the Krížna Nappe, Tatra Mountains. Annales Societatis Geologorum Poloniae, 84: 1-33.

Jenkyns, H.C., Clayton, C.J., 1986. Black shales and carbon isotopes in pelagic sediments from Tethyan Lower Jurassic. Sedimentology, 33: 87-106.

Jones, C.E., Jenkyns, H.C., Coe, A.L., Hesselbo, S.P., 1994 Strontium isotopic variations in Jurassic and Cretaceous seawater. Geochimica et Cosmochimica Acta, 58: 3061-3074.

Kirby, M.X., Soniat, T.M., Spero, H.J., 1998. Stable isotope sclerochronology of Pleistocene and Recent oyster shells (Crassostrea virginica). Palaios, 13: 560-569.

Kowalski, W.C., 1958. The Jurassic and Cretaceous in the western margin of the Łódź basin in the vicinity of Burzenin along the middle course of the Warta river (in Polish with English summary). Biuletyn Instytutu Geologicznego, 143: 1-160. 
Kutek, J., 1968. The Kimmeridgian and uppermost Oxfordian in the SW margins of the Holy Cross Mts. (Central Poland). Part 1. Stratigraphy (in Polish with English summary). Acta Geologica Polonica, 18: 493-586.

Kutek, J., 1994. Jurassic tectonic events in south-eastern cratonic Poland. Acta Geologica Polonica, 44: 167-221.

Kutek, J., Zeiss, A., 1997. The highest Kimmeridgian and Lower Volgian in Central Poland: their ammonites and biostratigraphy. Acta Geologica Polonica, 47: 107-198.

Lathuilière, B., Bartier, D., Bonnemaison, M., Boullier, A., Carpentier, C., Elie, M., Gaillard, C., Gauthier-Lafaye, F., Grosheny, D., Hantzpergue, P., Hautevelle, Y., Huault, V., Lefort, A., Malartre, F., Mosser-Ruck, R., Nori, L., Trouiller, A., Werner, W., 2015. Deciphering the history o climate and sea level in the Kimmeridgian deposits of Bure (eastern Paris Basin). Palaeogeography, Palaeoclimatology, Palaeoecology, 433: 20-48.

Manca, B., Burca, M., Giorgetti, A., Coatanoan, C., Garcia, M.-J., Iona, A., 2004. Physical and biochemical averaged vertical profiles in the Mediterranean regions: an important tool to trace the climatology of water masses and to validate incoming data from operational oceanography. Journal of Marine Systems, 48: 83-116.

Marshall, J.D., 1992. Climatic and oceanographic isotopic signals from the carbonate rock record and their preservation. Geological Magazine, 129: 143-160

Matyja, B.A., 1977. The Oxfordian in the south-western margin of the Holy Cross Mts. Acta Geologica Polonica, 27: 41-64.

Matyja, B.A., 2011. Płytkowodna platforma węglanowa późnej jury na południowo-zachodnim obrzeżeniu Gór Świętokrzyskich (in Polish). In: Jurassica IX, Małogoszcz, 06-08 września 2011. Materiały Konferencyjne. Polskie Towarzystwo Geologiczne Polska Grupa Robocza Systemu Jurajskiego: 133-151.

Matyja, B.A., Wierzbowski, A., 2006. Open shelf facies of the Polish Jura Chain. In: Jurassic of Poland and Adjacent Slovakian Carpathians (eds. A. Wierzbowski, R. Aubrecht, J. Golonka, J. Gutowski, M. Krobicki, B.A. Matyja, G. Pieńkowski and A. Uchman): 198-206. Field Trip Guidebook. 7th International Congress on the Jurassic System, 6-18 September 2006, Kraków, Poland.

Matyja, B.A., Wierzbowski, A., 2014. Górna jura synkliny tomaszowskiej (północno-zachodnie obrzeżenie mezozoiczne Gór Świętokrzyskich) (in Polish). In: Jurassica XI, Jurajskie Utwory Synkliny Tomaszowskiej, Przewodnik Wycieczek Terenowych, Abstrakty i Artykuły, Spała, 9-11.10.2014r.: 9-20. Państwowy Instytut Geologiczny - Państwowy Instytut Badawczy, Warszawa.

Matyja, B.A., Wierzbowski, A., 2016. Ammonites and ammonite stratigraphy of the uppermost Jurassic (Tithonian) of the Owadów-Brzezinki quarry (central Poland). Volumina Jurassica, 14: 65-122.

Matyja, B.A., Wierzbowski, A., Radwańska, U., Radwański, A., 2006. Stop B2.8 - Małogoszcz, large quarry of cement works (Lower and lowermost Upper Kimmeridgian). In: Jurassic of Poland and Adjacent Slovakian Carpathians (eds. A. Wierzbowski, R. Aubrecht, J.Golonka, J. Gutowski, M. Krobicki, B.A. Matyja, G. Pieńkowski and A. Uchman): 190-198. Field Trip Guidebook. 7th International Congress on the Jurassic System, 6-18 September 2006, Kraków, Poland.

Mettam, C., Johnson, A.L.A., Nunn, E.V., Schöne, B.R., 2014. Stable isotope $\left(\delta^{18} \mathrm{O}\right.$ and $\left.\delta^{13} \mathrm{C}\right)$ sclerochronology of Callovian (Middle Jurassic) bivalves (Gryphaea (Bilobissa) dilobotes) and belemnites (Cylindroteuthis puzosiana) from the Peterborough Member of the Oxford Clay Formation (Cambridgeshire, England): evidence of palaeoclimate, water depth and belemnite behaviour. Palaeogeography, Palaeoclimatology, Palaeoecology, 399: 187-201.

O'Neil, J.R., Clayton, R.N., Mayeda, T.K., 1969. Oxygen isotope fractionation in divalent metal carbonates. Journal of Chemical Physics, 51: 5547-5558.

Patterson, W.P., Walter, L.M., 1994. Depletion of ${ }^{13} \mathrm{C}$ in seawater $\Sigma \mathrm{CO}_{2}$ on modern carbonate platforms: significance for the carbon isotopic record of carbonates. Geology, 22: 885-888.
Price, G.D., Page K.N., 2008. A carbon and oxygen isotopic analysis of molluscan faunas from the Callovian-Oxfordian boundary at Redcliff Point, Weymouth, Dorset: implications for belemnite behaviour. Proceedings of the Geologists' Association, 119: 153-160.

Price, G.D., Teece, C., 2010. Reconstruction of Jurassic (Bathonian) palaeosalinity using stable isotopes and faunal associations. Journal of the Geological Society, 167: 1199-1208.

Price, G.D., Főzy, I., Pálfy, J., 2016. Carbon cycle history through the Jurassic-Cretaceous boundary: a new global $\delta^{13} \mathrm{C}$ stack. Palaeogeography, Palaeoclimatology, Palaeoecology, 451: 46-61.

Railsback, L.B., Anderson, T.F., Ackerly, S.C., Cisne, J.L., 1989 Paleoceanographic modeling of temperature-salinity profiles from stable isotopic data. Paleoceanography, 4: 585-591.

Riboulleau, A., Baudin, F., Daux, V., Hantzpergue, P., Renard, M., Zakharov, V., 1998. Évolution de la paléotemperature des eaux de la plate-forme russe au cours du Jurassique supérieur. Comptes Rendus de l'Académie des Sciences, Série $2 a-$ Sciences de la Terre et des Plančtes, 326: 239-246.

Rozanski, K., Araguás-Araguás, L., Gonfiantini, R., 1993. Isotopic patterns in modern global precipitation. Geophisical Monograph Series, 78: 1-36.

Savard, M.M., Veizer, J., Hinton, R., 1995. Cathodoluminescence at low Fe and Mn concentrations: a SIMS study of zones in natural calcites. Journal of Sedimentary Research, 65: 208-213.

Sellwood, B.W., Valdes, P.J., 2008. Jurassic climates. Proceedings of the Geologists' Association, 119: 5-17.

Shackleton, N.J., Kennett, J.P., 1975. Paleotemperature history of the Cenozoic and initiation of Antarctic glaciation: oxygen and carbon isotope analyses in DSDP sites 277,279 and 281. Initial Reports of the Deep Sea Drilling Project, 29: 743-755.

Sturman, N., Homkrajae, A., Manustrong, A., Somsa-ard, N., 2014. Observations on pearls reportedly from the Pinnidae family. Gems and Gemology, 50: 202-215.

Surge, D., Lohmann, K.C., Dettman, D.L., 2001. Controls on isotopic chemistry of the American oyster, Crassostrea virginica: implications for growth patterns. Palaeogeography, Palaeoclimatology, Palaeoecology, 172: 283-296.

Surge, D.M., Lohmann, K.C., Goodfriend, G.A., 2003. Reconstructing estuarine conditions: oyster shells as recorders of environmental change, Southwest Florida. Estuarine, Coastal and Shelf Science, 57: 737-756.

Swart, P.K., Oehlert, A.M., 2018. Revised interpretations of stable $\mathrm{C}$ and $\mathrm{O}$ patterns in carbonate rocks resulting from meteoric diagenesis. Sedimentary Geology, 364: 14-23.

Titschack, J., Zuschin, M., Spötl, C., Baal, C., 2010. The giant oyster Hyotissa hyotis from the northern Red Sea as a decadal-scale archive for seasonal environmental fluctuations in coral reef habitats. Coral Reefs, 29: 1061-1075.

Ullmann, C.V., Korte, C., 2015. Diagenetic alteration in low-Mg calcite from macrofossils: a review. Geological Quarterly, 59 (1): 3-20.

Ullmann, C.V., Wiechert, U., Korte, C., 2010. Oxygen isotope fluctuations in a modern North Sea oyster (Crassostrea gigas) compared with annual variations in seawater temperature: implications for palaeoclimate studies. Chemical Geology, 277: 160-166.

van Hinsbergen, D.J.J., de Groot, L.V., van Schaik, S.J., Spakman, W., Bijl, P.K., Sluijs, A., Langereis, C.G., Brinkhuis, H., 2015. A paleolatitude calculator for paleoclimate studies. Plos One, 10: e0126946.

Veizer, J., 1983. Chemical diagenesis of carbonates: theory and trace element technique. In: Stable Isotopes in Sedimentary Geology (eds. M.A. Arthur, T.F. Anderson, I.R Kaplan, J. Veizer and L.S. Land): 3-1-3-100. SEPM Short Course No. 10, Dallas.

Wierzbowski, H., 2015. Seawater temperatures and carbon isotope variations in central European basins at the Middle-Late Jurassic transition (Late Callovian-Early Kimmeridgian). Palaeogeography, Palaeoclimatology, Palaeoecology, 440: 506-523.

Wierzbowski, A., 2017. The Lower Kimmeridgian of the Wieluń Upland and adjoining regions in central Poland: lithostratigraphy, 
ammonite stratigraphy (upper Planula/Platynota to Divisum zones), palaeogeography and climate-controlled cycles. Volumina Jurassica, 15: 49-120.

Wierzbowski, H., Joachimski, M., 2007. Reconstruction of late Bajocian-Bathonian marine palaeoenvironments using carbon and oxygen isotope ratios of calcareous fossils from the Polish Jura Chain (central Poland). Palaeogeography, Palaeoclimatology, Palaeoecology, 254: 523-540.

Wierzbowski, A., Głowniak, E., 2018. The Early Kimmeridgian succession at Kodrąb (Radomsko elevation, central Poland) and its palaeogeographical and palaeotectonic implications. Geological Quarterly, 62 (3): 509-521.

Wierzbowski, A., Rogov, M.A., 2013. Biostratigraphy and ammonites of the Middle Oxfordian to lowermost Upper Kimmeridgian in northern Central Siberia. Russian Geology and Geophysics, 54: 1083-1102.

Wierzbowski, H., Rogov, M.A., Matyja, B.A., Kiselev, D., Ippolitov, A., 2013. Middle-Upper Jurassic (Upper Callovian-Lower Kimmeridgian) stable isotope and elemental records of the Russian Platform: indices of oceanographic and climatic changes. Global and Planetary Change, 107: 196-212.

Wierzbowski, H., Dubicka, Z., Rychliński, T., Durska, E., Olempska, E., Błażejewski., B., 2016. Depositional environ- ment of the Owadów-Brzezinki conservation Lagerstätte (upermost Jurassic, central Poland): evidence from microfacies analysis, microfossils and geochemical proxies. Neues Jahrbuch für Geologie und Paläontologie, Abhandlungen, 282: 81-108.

Wierzbowski, H., Bajnai, D., Wacker, U., Rogov, M.A., Fiebig, J., Tesakova, E.M., 2018. Clumped isotope record of salinity variations in the Subboreal Province at the Middle-Late Jurassic transition. Global and Planetary Change, 167: 172-189.

Zakharov, V.A., Baudin, F., Dzyuba, O.S., Daux, V., Zverev, K.V., Renard, M., 2005. Isotopic and faunal record of high paleotemperatures in the Kimmeridgian of Subpolar Urals. Russian Geology and Geophysics, 46: 3-20.

Zuo, F., Heimhofer, U., Huck, S., Bodin, S., Erbacher, J., Bai, H., 2018. Coupled $\delta^{13} \mathrm{C}$ and ${ }^{87} \mathrm{Sr} /{ }^{86} \mathrm{Sr}$ chemostratigraphy of Kimmeridgian shoal-water deposits: A new composite record from the Lower Saxony Basin, Germany. Sedimentary Geology, 376: 18-31.

Zuo, F., Heimhofer, U., Huck, S., Adatte, T., Erbacher, J., Bodin, S., 2019. Climatic fluctuations and seasonality during the Kimmeridgian (Late Jurassic): stable isotope and clay mineralogical data from the Lower Saxony Basin, Northern Germany. Palaeogeography, Palaeoclimatology, Palaeoecology, 517: 1-15. 